\title{
The development of HIV vaccines targeting gp41 membrane-proximal external region (MPER): challenges and prospects
}

\author{
Huan Liu ${ }^{1 \bowtie}$, Xiaojie $\mathrm{Su}^{2}$, Lulu Si ${ }^{2}$, Lu Lu ${ }^{2 \bowtie}$, Shibo Jiang ${ }^{2,3 \bowtie ~}$ \\ ${ }^{1}$ State Key Laboratory of Virology, Wuhan Institute of Virology, Chinese Academy of Sciences, Wuhan 430071, China \\ ${ }^{2}$ Key Laboratory of Medical Molecular Virology of MOE/MOH, School of Basic Medical Sciences \& Shanghai Public Health \\ Clinical Center, Fudan University, Shanghai 200032, China \\ ${ }^{3}$ New York Blood Center, Lindsley F. Kimball Research Institute, New York, NY 10065, USA \\ $\bowtie$ Correspondence: liuhuan@wh.iov.cn (H. Liu), lul@fudan.edu.cn (L. Lu), shibojiang@fudan.edu.cn (S. Jiang) \\ Received February 4, 2018 Accepted March 5, 2018
}

\begin{abstract}
A human immunodeficiency virus type-1 (HIV-1) vaccine which is able to effectively prevent infection would be the most powerful method of extinguishing pandemic of the acquired immunodeficiency syndrome (AIDS). Yet, achieving such vaccine remains great challenges. The membrane-proximal external region (MPER) is a highly conserved region of the envelope glycoprotein (Env) gp41 subunit near the viral envelope surface, and it plays a key role in membrane fusion. It is also the target of some reported broadly neutralizing antibodies (bNAbs). Thus, MPER is deemed to be one of the most attractive vaccine targets. However, no one can induce these bNAbs by immunization with immunogens containing the MPER sequence(s). The few attempts at developing a vaccine have only resulted in the induction of neutralizing antibodies with quite low potency and limited breadth. Thus far, vaccine failure can be attributed to various characteristics of MPER, such as those involving structure and immunology; therefore, we will focus on these and review the recent progress in the field from the following perspectives: (1) MPER structure and its role in membrane fusion, (2) the epitopes and neutralization mechanisms of MPER-specific bNAbs, as well as the limitations in eliciting neutralizing antibodies, and (3) different strategies for MPER vaccine design and current harvests.
\end{abstract}

KEYWORDS HIV-1, gp41, MPER, vaccine, neutralizing antibodies, ADCC

\section{INTRODUCTION}

Acquired immunodeficiency syndrome (AIDS) is an infectious disease caused by human immunodeficiency virus (HIV) infection, which can impair and even destroy the human immune system. Since its discovery in 1983, AIDS has spread worldwide with more than 36.7 million people who are living with HIV infection, thus calling for development of effective and safe vaccines to prevent HIV infection and end the current AIDS pandemic. The statistical analysis based on a mathematical model predicts that application of a $50 \%$-efficacy vaccine starting from 2020 and gradually scaling up to $70 \%$ coverage by 2035 will avert 17 million new infections if the current conditions of diagnosis and treatment keep unchanged (Medlock et al., 2017).

In spite of efforts for more than 30 years and hundreds of clinical trials, most HIV vaccine clinical trials have failed and none of the HIV vaccines has been approved so far. The RV144 vaccine trial that was launched in Thailand in 2009 is the only clinical trial showing an efficacy of $31.2 \%$ reduction of HIV type 1 (HIV-1) infection (Kim et al., 2015), and since then, no more effective HIV-1 vaccine has been developed. However, several groups have discovered some vaccine targets on the virus surface which play an important role in the infection process, such as the CD4 binding site $(\mathrm{Wu}$ et al., 2009), V1V2 region (Wang et al., 2017) and membrane-proximal external region (MPER: ${ }_{659}$ ELLELDK WASLWNWFDITNW LWYIK 683 , HXB2 numbering) (Sun et al., 2016). All these targets are located on the HIV-1 Env. Eliciting broadly neutralizing antibodies (bNAbs) against these targets, i.e., antibodies that can neutralize a broad 
spectrum of HIV-1 strains, is one of major goals for designing a successful HIV-1 vaccine (Haynes and Mascola, 2017).

MPER is a highly conserved motif in the HIV-1 Env gp41 subunit near the viral envelope surface. It plays an important role in membrane fusion, and it is the target of some reported bNAbs. Thus, MPER is deemed to be one of the most promising vaccine targets. Multiple monoclonal antibodies (mAbs) against this region have been reported so far, such as 2F5, 4E10, Z13, Z13e1, m66.6, CH12 and 10E8 (Muster et al., 1993; Muster et al., 1994; Stiegler et al., 2001; Zwick et al., 2001; Nelson et al., 2007; Hessell et al., 2010; Morris et al., 2011; Huang et al., 2012; Ofek et al., 2014). Among these antibodies, 2F5, 4E10 and 10E8 exhibit broadly neutralizing activity, but these kinds of bNAbs cannot be elicited in animals through immunization. Many attempts have been made to develop vaccines targeting MPER, but only a small number of them can induce neutralizing antibodies and then only with low potency and limited neutralizing breadth. The reasons for vaccine failure may, on one hand, involve the ambiguous conformation of MPER. The native conformation of MPER, or the conformation capable of inducing neutralizing antibodies, has not been determined, and the change of MPER conformation during the membrane fusion process also has not been elucidated. On the other hand, MPERspecific bNAbs possess the cross-reactivity with human autoantigens, and it has been demonstrated that the mechanism of host tolerance mechanism impairs MPER-specific neutralization responses (Kelsoe and Haynes, 2017). These open questions serve to compound the difficulties in designing immunogens and immunization protocols.

This review will focus on recent progress in the field from the following perspectives: (1) MPER structure and its role in membrane fusion, (2) the neutralizing epitopes in MPER and neutralization mechanisms of MPER-specific bNAbs, as well as the limitations in eliciting neutralizing antibodies, and (3) different strategies for MPER vaccine design and current harvests. Understanding the properties and characteristics of MPER structure and immunology, as viewed from these perspectives, will not only be helpful in analyzing how they pose obstacles to vaccine development, but also provide some tentative guidelines for designing reasonable immunogens and vaccines with the hope of ultimately designing an effective HIV vaccine and inducing MPERspecific bNAbs.

\section{STRUCTURE AND FUNCTION OF GP41 MPER: A DILEMMA OF UNKNOWN CONFORMATIONS}

HIV-1 Env is the sole viral antigen exposed on the virion surface. It is first synthesized as a gp160 glycoprotein precursor and then cleaved into a mature complex constituted by the noncovalent association of three gp120 (surface) and three gp41 (transmembrane) subunits, forming a highly glycosylated trimer of heterodimers (Wyatt et al., 1998; Zanetti et al., 2006; Liu et al., 2008). As C-terminus of the gp41 subunit ectodomain, gp41 MPER bridges the extracellular domain and transmembrane region of Env (Munoz-Barroso et al., 1999; Salzwedel et al., 1999) (Fig. 1), which is a highly conserved motif near the viral envelope surface. The steric hindrance of gp120 and the high hydrophobicity of MPER make MPER partly embedded in the viral membrane (Sun et al., 2008), making it difficult to resolve the native conformation of MPER in the envelope glycoprotein trimer (Lee et al., 2016). In addition, the epitopes of the reported bNAbs reveal quite different conformations so that multiple conformations may be associated with the induction of neutralizing antibodies. During the fusion process, gp41 will undergo dramatic structural changes, which results in continuous contact between the immune system and MPER with different conformations. However, the exact conformations that manifest in the membrane fusion process are still not clear. Thus, the problem of unknown conformations hinders immunogen design.

\section{Structure of gp41 MPER}

The native structure of MPER is still unclear. Previous studies have put forth two different structural models by cryoelectron tomography (Zanetti et al., 2006; Zhu et al., 2006). Zhu et al. have proposed that MPER and the transmembrane (TM) regions, as the stalk of each trimer, are composed of three separate legs that obliquely stretch out of the trimer's head, much like a tripod. Some researchers hold that such tripod-like model is consistent with the present views concerning gp41 MPER interaction with the membrane (Zhu et al., 2006; Buzon et al., 2010). In contrast, the structural model proposed by Zanetti et al. shows the TM region of simian immunodeficiency virus (SIV) gp41 as a stem in the viral surface. These conflicting structures may be attributed to different methods used to collect the data and/or the computational approaches used to determine the structures (Subramaniam, 2006). The recent study of Dev et al. supports the stem model of TM (Dev et al., 2016). Using cryogenic electron microscopy, Lee et al. analyzed a clade B virus Env lacking only the cytoplasmic tail stabilized by 10E8. The result of nuclear magnetic resonance (NMR) suggests that MPER is embedded in the membrane and that MPER and heptad repeat 2 (HR2) are connected flexibly (Lee et al., 2016). So far, the native conformation of MPER is still fuzzy (Lee et al., 2016) and requires further study.

NMR and surface plasmon resonance (SPR), among other technologies, show that MPER adopts an $\alpha$ helical conformation partially embedded in the viral membrane, consisting of two independent domains separated by a flexible hinge (Sun et al., 2008; Song et al., 2009). These two segments show different membrane-interacting attributes such that the C-terminal domain is embedded in the membrane, and the $\mathrm{N}$-terminal domain is more exposed. Owing to amphiphilic characteristics of the C-terminal domain, the hydrophobic residues are buried in the membrane, whereas the polar residues are solvent-exposed (Huarte et al., 2008; 
HIV-1 Env (gp120/gp41)
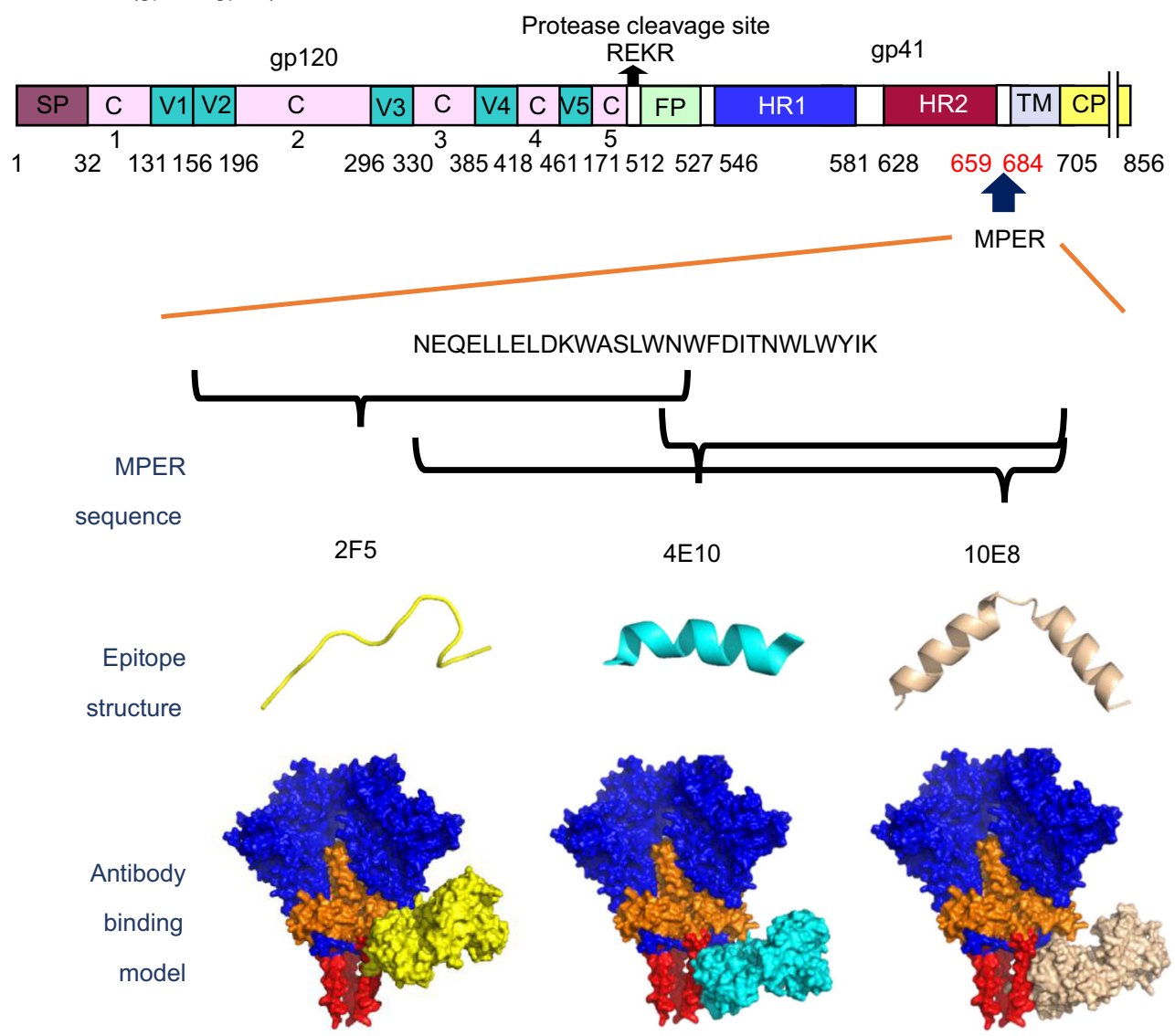

Figure 1. MPER in the envelope glycoproteins of HIV-1 and conformation of MPER binding to antibodies. As C-terminus (aa 660-683, HXB2 numbering) of gp41 subunit ectodomain, gp41 MPER bridges the extracellular domain and transmembrane region of Env. The crystal structure of 2F5 Fab in complex with its epitope peptide (PDB ID code: 1TJI) reveals that its epitope forms a $\beta$ turn conformation, whereas epitope of 4E10 (PDB ID code: 2FX7) forms an a helical conformation. Similar to 4E10, 10E8 forms two $\alpha$ helixes at $\mathrm{N}$ - and $\mathrm{C}$-terminus of MPER, respectively. Blue in the figure indicates gp120, orange indicates gp41, and red indicates MPER. The epitope and Fab of 2F5, 4E10 and 10E8 are represented by yellow, cyan and brown, respectively.

Sun et al., 2008; Song et al., 2009; Kim et al., 2013). Moreover, MPER exhibits different conformations when bound by antibodies (Fig. 1). As shown in Figure 1, the crystal structure of $2 \mathrm{~F} 5 \mathrm{Fab}$ in complex with its epitope peptide reveals that the ${ }_{664} \mathrm{DKW}_{666}$ core motif forms a $\beta$ turn conformation (Bryson et al., 2001). In contrast, the crystal structure of Fab 4E10 in complex with its epitope peptide was found to form an a helical conformation from D674 to K683 (Cardoso et al., 2005; Cardoso et al., 2007). Similar to $4 \mathrm{E} 10$, the crystal structure of Fab 10E8 in complex with its epitope peptide also forms an a helical conformation (Huang et al., 2012). These results indicated that MPER is natively flexible, indicating that more than one structure is associated with neutralization and, at the same time, implying that multiple conformations of MPER immunogens may be favorable to the induction of bNAbs. However, it remains puzzling whether some kind of conformation, or several kinds, can be applied to vaccine design.

\section{Role of gp41 MPER in the membrane fusion process}

The HIV-1 Env transmembrane subunit gp41 serves to anchor the Env protein to cellular membranes and mediate membrane fusion during virus entry into the cell (Chan and Kim, 1998). When the membrane fusion process initiates, gp120 interacts with CD4 molecule on the surface of target cells with a high affinity, which facilitates a series of conformational changes. The gp120 coreceptor binding site is exposed transiently, allowing gp120 attachment to the CCR5 or CXCR4 chemokine receptor (Maddon et al., 1986; McDougal et al., 1986; Rizzuto et al., 1998). Coreceptor ligation triggers the structural rearrangement of gp41, allowing the gp41 fusion peptide (FP) to insert into the target 
cell membrane, which accounts for a transient prehairpin fusion intermediate, and the cellular and viral membrane are linked by gp41 with an extended conformation. Then $\alpha$ helical domains HR1 and HR2 of each gp41 monomer are reversibly folded into a 6 -helix bundle $(6-\mathrm{HB})$ conformation (Su et al., 2017a; Su et al., 2017b), bringing both cellular and viral membrane closer to ultimately generate membrane fusion (Blumenthal et al., 2012; Klasse, 2012).

The entire gp41 is mostly occluded by gp120 in the native virus spike where MPER is exposed transiently in the fusion process (Dimitrov et al., 2007). As such, the importance of MPER in the function of Env is highlighted by analyses of mutant viruses involving MPER deletions, insertions and substitutions (Munoz-Barroso et al., 1999; Dimitrov et al., 2007; Vishwanathan and Hunter, 2008). For example, substitution of the five conserved tryptophan residues in MPER greatly compromises the integration of gp41 into virions and, consequently, blocks viral entry (Munoz-Barroso et al., 1999). In addition, deletion of the 666WASLWNWFDITNWLWYI682 region completely abolishes the formation of syncytium. Such evidence shows that MPER plays an important role in HIV-1 Env-mediated fusion and virus infection, which is consistent with the high conservatism of its sequence (Salzwedel et al., 1999). In addition, some studies has indicated that MPER may mediate membrane partition, fusion and penetration (Suarez et al., 2000a; Suarez et al., 2000b). MPER plays a key role in membrane destabilization by interacting with the lipid membrane (Bellamy-Mclntyre et al., 2007). The high content of tryptophan may enable MPER to interact with the lipid membrane and destabilize it (Suarez et al., 2000b; Stano et al., 2005). Some studies have also revealed that MPER plays a role in HIV-1 CD4-independent viral transcytosis at the epithelial barrier (Bomsel, 1997) where the conserved sequence 662ELDKWA667 interacts with galactosyl ceramide receptors (Alfsen and Bomsel, 2002), indicating that MPER is functional in the mucosal infection of viruses. The secretory $\lg \mathrm{A}$ from cervicovaginal secretions of HIV-1-infected individuals can block viral transcytosis though binding the 662ELDKWA667 sequence (Alfsen et al., 2001; LerouxRoels et al., 2013), indicating that the use of an immunogen containing MPER is likely to induce vaginal $\lg A$ with transcytosis-blocking activity, a finding also confirmed by another report (Bomsel et al., 2011). Therefore, eliciting antibodies against MPER by vaccination may disturb its function thus effectively block viral entry and protect humans from HIV-1 infection.

To sum up, a number of groups have shown that MPER is conserved and plays important roles in the course of viral infection. However, researchers have not yet determined the exact structure of gp41, the native conformation of MPER, or the conformation of MPER capable of inducing neutralizing antibodies, let alone the allosteric mode of gp41, especially MPER during the membrane fusion process. Consequently, we have a dilemma of unknown conformations that seriously militates against successful immunogen design. Apart from such parameters as low accessibility and unknown conformations, the host tolerance mechanism also influences MPER-specific neutralization responses. We will discuss the humoral responses targeting MPER in detail below.

\section{HUMORAL RESPONSES TARGETING MPER: COEXISTENCE OF HOPES AND LIMITATIONS}

In the earlier clinical trials, HIV-1 Env-based subunit vaccines were tested to elicit antibodies specific for gp120. However, these antibodies had no neutralizing activity and vaccinated people were not protected from HIV infection. The failure of these trials promoted a shift to the development of HIV vaccines for eliciting T cell responses. However, the disappointing outcome from the clinical trials of a T cellbased vaccine regimen, the STEP trial, conducted by Merck and HIV Vaccine Trials Network (HVTN), has dealt another setback to AIDS vaccine development (Miedema, 2008). The failure of the STEP trial further reinforced the notion that an effective AIDS vaccine needs to induce both strong CTLS (cytotoxic T lymphocytes) and bNAbs against HIV infection (Barouch, 2008; Fauci et al., 2008; Walker and Burton, 2008). Moreover, as mentioned in the section above, the contribution of IgAs at the mucosal surface also should not be ignored (Bomsel, 1997).

Nevertheless, efforts to engineer vaccines that can induce HIV bNAbs have encountered great difficulties; no one can induce bNAbs by immunization with immunogens containing MPER sequence(s). To gain a better understanding of this, we will analyze (1) the neutralizing epitopes in MPER and neutralization mechanisms of MPER-specific bNAbs and (2) limitations in the elicitation of neutralizing antibodies. The neutralization mechanisms of bNAbs highlight the importance of membrane and show the role of lipids as a native scaffold to shape the structure of MPER, in turn suggesting the importance of lipids in immunogen design. In addition, the limitations of inducing neutralizing antibodies put more burdens on vaccine design.

\section{Epitopes and neutralization mechanisms of three bNAbs}

The mAbs isolated from HIV-1-infected individuals are the strongest evidence proving that the human immune system can generate MPER-specific neutralization responses. Multiple mAbs targeting MPER have been isolated so far, such as 2F5, 4E10, Z13, Z13e1, m66.6, CH12 and 10E8 (Muster et al., 1993; Muster et al., 1994; Stiegler et al., 2001; Zwick et al., 2001; Nelson et al., 2007; Hessell et al., 2010; Morris et al., 2011; Huang et al., 2012; Ofek et al., 2014). Among these antibodies, 2F5, 4E10 and 10E8 reveal broadly neutralizing activity, and as such, they have been explored more thoroughly (Table 1).

$2 \mathrm{~F} 5$ and $4 \mathrm{E} 10$ are among the first bNAbs discovered that were generated by electrofusion of peripheral blood mononuclear cell mixtures from different HIV-1-infected 
Table 1. Features of the reported bNAbs against MPER.

\begin{tabular}{llllll}
\hline Antibody & Binding sequence & No. of viruses & $\mathrm{IC}_{50}<50 \mu \mathrm{g} / \mathrm{mL}$ & $\mathrm{IC}_{50}<1 \mu \mathrm{g} / \mathrm{mL}$ & $\mathrm{Mean} \mathrm{IC}{ }_{50}(\mu \mathrm{g} / \mathrm{mL})$ \\
\hline 2 F5 & ${ }_{656}$ NEQELLELDKWASLWN ${ }_{671}$ & 177 & $57 \%$ & $16 \%$ & 1.92 \\
$4 \mathrm{E} 10$ & ${ }_{671}$ NWFDITNWLWYIK $_{683}$ & 181 & $98 \%$ & $37 \%$ & 1.3 \\
$10 \mathrm{E} 8$ & ${ }_{664}$ DKWASLWNWFDITNWLWYIK $_{683}$ & 180 & $98 \%$ & $72 \%$ & 0.22 \\
\hline
\end{tabular}

individuals (Buchacher et al., 1994). 2F5 targets the sequence ${ }_{656} \mathrm{NEQELLELDKWASLWN}{ }_{671}$ within the N-terminus of MPER (Muster et al., 1993), of which the central core, ${ }_{664} \mathrm{DKW}_{666}$, is crucial to neutralization, as demonstrated by alanine-scanning mutagenesis assays (Zwick et al., 2005). The crystal structures of $2 F 5$ in complex with a synthesized short or long peptide based on its epitope have been analyzed, and the results showed that the ${ }_{664} \mathrm{DKW}_{666}$ core motif presents a $\beta$ turn conformation. The structure of $2 \mathrm{~F} 5$ in complex with the long peptide reveals that only $41 \%$ of its sequence binds $2 \mathrm{~F} 5$ with some unbound hydrophobic regions, which may be subject to the steric hindrance of Env or embedded in the lipid membrane (Ofek et al., 2004; Bryson et al., 2008). 2F5 has a relatively high potency and can neutralize $57 \%-67 \%$ of viral isolates with a concentration causing $50 \%$ inhibition of the desired activity $\left(\mathrm{IC}_{50}\right)$ below 50 $\mu \mathrm{g} / \mathrm{mL}$ (Binley et al., 2004; Huang et al., 2012). However, as a result of a mutation in the central core epitope (DSW instead of DKW), HIV-1 C subtype viruses are usually 2F5resistant (Bures et al., 2002; Binley et al., 2004; Gray et al., 2006).

4E10 targets the distal conserved tryptophan-rich motif that is located C-terminal to the 2F5 epitope, including the sequence ${ }_{671}$ NWFDIT $_{676}$, and extending toward C-terminal residues where W672, F673, 1675, T676, L679 and W680 have the most important contact with the antibody (Zwick et al., 2001). Although presenting a moderate potency, 4E10 displays a remarkable breadth to neutralize $98 \%-100 \%$ viral isolates with an $\mathrm{IC}_{50}$ below $50 \mu \mathrm{g} / \mathrm{mL}$ (Binley et al., 2004; Walker et al., 2009). Compared with the pseudoviruses obtained in 293 T cells, further characterization of $2 \mathrm{~F} 5$ and 4E10 revealed their reduced potency against transmitted/founder viruses (T/F IMC) or replicating viruses obtained from primary lymphocytes (Louder et al., 2005; Provine et al., 2009; Provine et al., 2012; Miglietta et al., 2014). In spite of these possible limitations, both $2 \mathrm{~F} 5$ and 4E10 were shown to protect nonhuman primates (NHP) against viral challenge (Mascola et al., 2000; Hessell et al., 2010), and no major clinical complication arose when administered to human recipients (Trkola et al., 2005).

In order to delineate a complete map of HIV-1 neutralizing determinants, substantial efforts have been made to isolate new bNAbs since 2009. The development of high-throughput analysis of single memory B cells and the use of fluorescently labeled Env-based protein probes to isolate antigenspecific B cells have significantly contributed toward the discovery of new HIV-1 neutralizing antibodies (Doria-Rose et al., 2009; Scheid et al., 2009; Wu et al., 2010). In this context, mAb 10E8 discovered in 2012 proved once again that important bNAbs targeting this area can be generated. It also prompted researchers to consider MPER as a major vaccine target (Huang et al., 2012).

10E8 targets the sequence ${ }_{656}$ NEQELLELDKWASLWN ${ }_{671}$ within the C-terminus of MPER, which overlaps the epitopes of $2 \mathrm{~F} 5$ and $4 \mathrm{E} 10$. It neutralized $98 \%$ of 181 pseudoviruses with an $\mathrm{IC}_{50}$ below $50 \mu \mathrm{g} / \mathrm{mL}$, showing a mean $\mathrm{IC}_{50}$ of $0.25 \mu \mathrm{g} / \mathrm{mL}$ for the sensitive viruses, while mean $\mathrm{IC}_{50}$ values of $4 \mathrm{E} 10$ and $2 \mathrm{~F} 5$ were 1.3 and $1.92 \mu \mathrm{g} / \mathrm{mL}$, respectively. Interestingly, $72 \%$ of the panel was neutralized by $10 \mathrm{E} 8$ with an $\mathrm{IC}_{50}$ below $1 \mu \mathrm{g} / \mathrm{mL}$, while the percentages of $4 \mathrm{E} 10$ and $2 \mathrm{~F} 5$ were $37 \%$ and $16 \%$, respectively (Huang et al., 2012). Therefore, 10E8 can neutralize viruses with a greater potency and breadth than the previously discovered $2 \mathrm{~F} 5$ and $4 \mathrm{E} 10$, and it is comparable to some of the most potent bNAbs, such as VRC01 or PG9/PG16 (West et al., 2014). Notably, 10E8 was also reported to protect NHP against viral challenge (Pegu et al., 2014).

Just recently, a new lineage of MPER-specific bNAbs, designated DH511, was isolated from memory B cells and plasma of an HIV-1-infected donor (Williams et al., 2017). The DH511 lineage, which is derived from the same heavy chain germline gene family $(\mathrm{VH} \mathrm{3-15)}$ as 10E8, presents long CDR $\mathrm{H} 3$ loops of 23 to 24 amino acids, and the somatic mutation rates of $\mathrm{VH}$ and $\mathrm{VL}$ are $15 \%-22 \%$ and $14 \%-18 \%$, respectively. $\mathrm{DH} 511.2$, as the most potent $\mathrm{mAb}$ of this clone lineage, neutralized 206 out of 208 pseudoviruses of a geographically and genetically diverse panel with a median $\mathrm{IC}_{50}$ of $1 \mu \mathrm{g} / \mathrm{mL}$, being slightly broader, but less potent, than 10E8 (Williams et al., 2017).

Independent of their origin, all these antibodies are the product of a long process of affinity maturation, which is highly mutated with an unusually long and hydrophobic heavy chain complementary determining region 3 (CDR H3) (Zwick et al., 2004; Cardoso et al., 2005; Huang et al., 2012). In addition, these antibodies share a similar neutralization mechanism. Although some residues of the CDRs are very important for binding peptidic epitopes, researches have shown that the most hydrophobic loops directly interact with membrane lipid (Alam et al., 2007; Alam et al., 2009; Lutje Hulsik et al., 2013). In previous study, 2F5 was predicted to bind lipids via CDRL1 and CDRH3 (Julien et al., 2008). Recently, lipid-binding sites of 4E10 and 10E8 were determined by X-ray crystallography (Irimia et al., 2016; Irimia et al., 2017). The bNAbs against MPER binding to a peptide 
sequence obey the Langmuir curve model, but SPR-based studies demonstrated that binding polypeptide-membrane complex follows a two-step (encounter-docking) model. First, the antibody attaches to the lipid membrane through its long hydrophobic CDR $\mathrm{H} 3$ and concentrates around the MPER epitope. Once conformational changes take place, the antibody binds to the pre-hairpin intermediate of gp41 (Alam et al., 2007; Alam et al., 2009). The mechanism facilitates the approach of antibody to epitope, overcoming the poor exposure of MPER and also taking advantage of its close proximity to the viral membrane. However, the exact neutralization mechanism is still controversial and requires further exploration (Frey et al., 2008; Kim et al., 2014).

In sum, all epitopes of bNAbs targeting MPER may be composed of peptidic residues and membrane lipids together. The importance of membrane in the neutralization mechanism of bNAbs shows the important role of lipids as a native scaffold in shaping the structure of MPER, thus indicating the significance of lipids in immunogen design. Therefore, in order to generate MPER-specific neutralization responses, the membrane environment may be required to present the neutralizing determinant properly.

Generation of neutralizing antibodies: limited by polyreactivity/autoreactivity

Up to now, the reported bNAbs against MPER have a prevalence of polyreactivity and autoreactivity. In 2005, the polyspecific binding of $4 \mathrm{E} 10$ and $2 \mathrm{~F} 5 \mathrm{mAbs}$ to cardiolipin and other anionic phospholipids was reported (Haynes et al., 2005a). Furthermore, conserved host antigens bound by 2F5, 4E10 and 10E8 were also identified (Yang et al., 2013; Liu et al., 2015). 2F5 binds to the enzyme kynureninase (KYNU) containing the same sequence (ELDKWA) as its epitope, which is highly conserved in different mammal species. 4E10 binds to splicing factor-3b subunit-3 and type I inositol triphosphate (IP3R1) (Yang et al., 2013). Although considered as non-polyreactive initially, subsequent studies indicated that 10E8 possibly needs to bind membrane lipids, especially cholesterol, to mediate neutralization (Huang et al., 2012; Chen et al., 2014; Irimia et al., 2017). Recently, the crystal structure of 10E8 in complex with MPER shaped by a scaffold revealed that its complete epitope consists of MPER and lipids (Irimia et al., 2017). Although described as non-autoreactive initially, 10E8 also recognizes FAM84A protein (Liu et al., 2015); however, such recognition did not seem to cause strong toxicity in vivo since clinical trials showed 2F5, 4E10 and 10E8 to be relatively safe (Trkola et al., 2005; Pegu et al., 2014).

These studies reporting on polyreactivity and autoreactivity suggest that autoreactive B cells that cross-react with MPER sequences may be impaired in the native repertoire. Thus, this immunologic tolerance mechanism might be associated with HIV-1 evasion of immune responses (Haynes et al., 2005b; Verkoczy et al., 2014). This hypothesis was confirmed by monitoring $B$ cell development in knockin $(\mathrm{KI})$ mouse models carrying $\mathrm{V}$ (D) $\mathrm{J}$ rearrangements identical to those of the mature bNAbs $2 \mathrm{~F} 5$ and $4 \mathrm{E} 10$. These models showed a normal early $B$ cell development, but a blockade from pre-B to immature $\operatorname{lgM}^{+} B$ cells at the first tolerance checkpoint (Verkoczy et al., 2010; Doyle-Cooper et al., 2013; Verkoczy et al., 2013; Verkoczy and Diaz, 2014). B cell central tolerance takes place in the bone marrow, hindering the development of autoreactive B cells by several mechanisms, such as clonal deletion and receptor editing ( $\mathrm{Ne}$ mazee, 2017). After that, some autoreactive B cells can still migrate from the bone marrow as anergic cells, showing a hyporesponsive state and a shortened lifespan. However, under special circumstances, the anergic $B$ cells can be activated and differentiate into antibody-producing $B$ cells (von Boehmer and Melchers, 2010). Consistent with this phenomenon, when $2 \mathrm{~F} 5 \mathrm{KI}$ mice were immunized with MPER peptide-liposome immunogens, anergic $B$ cells could be restored to generate specific neutralizing antibodies (Dennison et al., 2009; Verkoczy et al., 2011). More recently, a 2F5 germline knock-in (KI) mice model has demonstrated that remaining anergic $B$ cells can also be activated by germline-mimicking immunogens when 2F5 precursors are deleted (Zhang et al., 2016). All these results indicated that the production of $2 \mathrm{~F} 5$ and $4 \mathrm{E} 10$ antibodies may be controlled by immunologic tolerance mechanisms (Yang et al., 2013; Liu et al., 2015).

Impairment of autoreactive B cells that cross-react with MPER sequences in the native repertoire can also explain the low frequency of MPER neutralizing antibodies during the course of natural infection (Haynes et al., 2005a; Haynes et al., 2005b; Kelsoe and Haynes, 2017). The characterization of different cohorts in Europe, America and South Africa indicated that MPER-specific neutralizing responses are less represented compared with other epitopes during natural infection. For example, in a South African cohort of 156 HIV-1-infected individuals, only three showed high titers of anti-MPER antibodies (Gray et al., 2009), and depletion of these antibodies resulted in the loss of neutralization breadth. A recent study analyzed the neutralization profile of 439 plasma samples and demonstrated far less prevalence of MPER-specific antibodies compared with other epitopes, mainly the V3 N332-dependent glycan supersite (Landais et al., 2016).

Judging from the results of these studies, we might assume the following steps (Fig. 2). When developing in the bone marrow, pre-B cells that possibly produce bNAbs later always bind lipids (or other autoantigens); therefore most of them are removed by clonal deletion and receptor editing and accordingly cannot develop into immature $\operatorname{lgM}^{+} \mathrm{B}$ cells. However, a few lipid-reactive (or other autoantigens) B cells can still migrate from the bone marrow to the secondary lymphoid organ as anergic cells which can be activated again by antigens, such as MPER-lipid complex, similar to lipids (or other autoantigens), and differentiate into antibodyproducing B cells. Since only a small number of anergic cells 
Host control of broadly neutralizing antibody induction

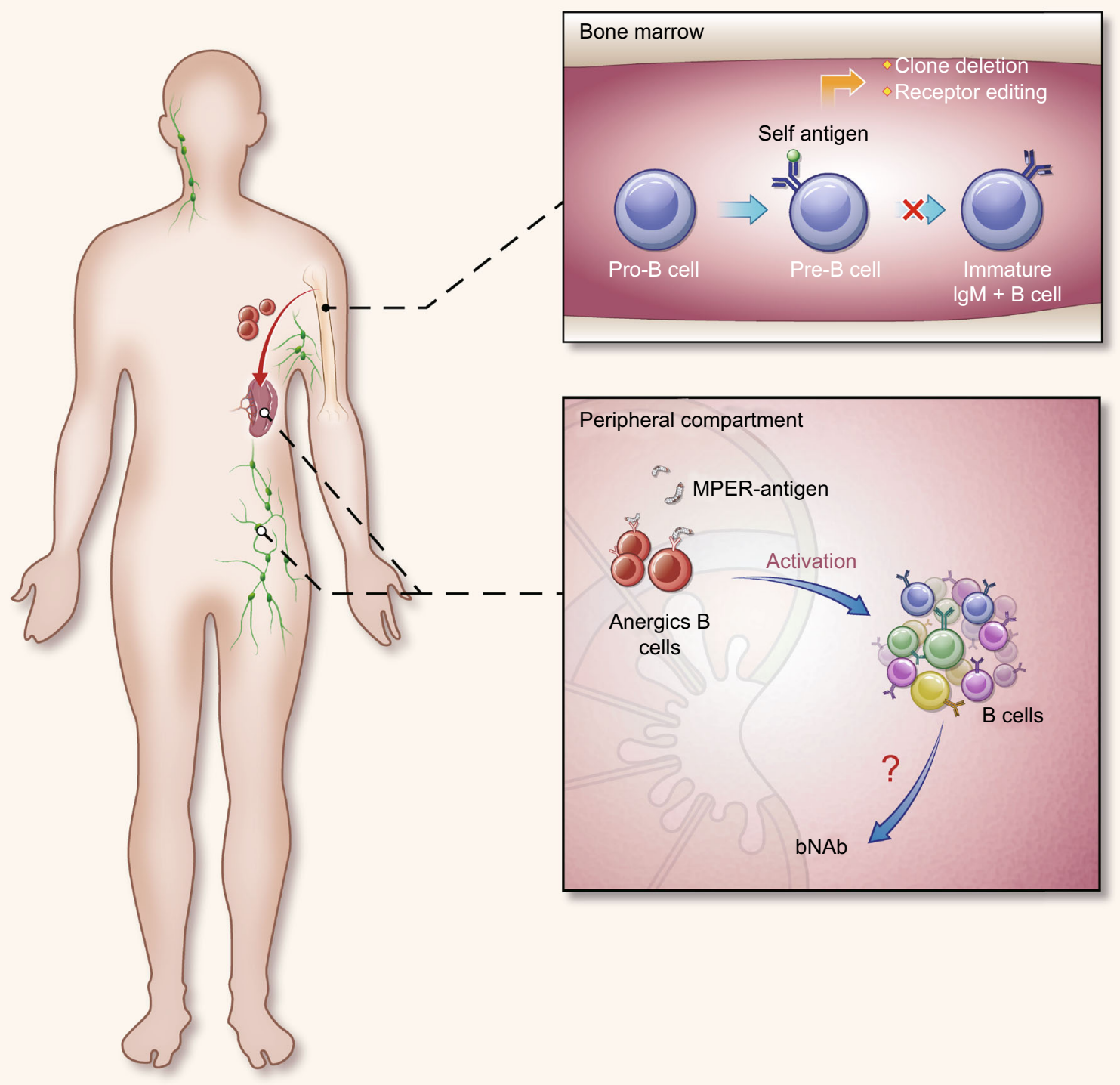

Figure 2. Host control of bNAbs induction. When developing in the bone marrow, pre-B cells that possibly produce bNAbs later always bind the lipids (or other autoantigens); therefore most of them are removed by clonal deletion and receptor editing and accordingly cannot develop into immature IgM $^{+}$B cells. However, a few lipid-reactive (or other autoantigens) B cells can still migrate from the bone marrow to the secondary lymphoid organ as anergic cells which can be activated again by antigens, such as MPERlipid complex, similar to lipids (or other autoantigens), and differentiate into antibody-producing B cells. Since only a small number of anergic cells can move to the secondary lymphoid organ, the difficulty of generating bNAbs cannot be understated.

can move to the secondary lymphoid organ, the difficulties of generating bNAbs are far-reaching. Therefore, how antiMPER bNAbs can be induced is still a key issue worthy of consideration.

\section{VACCINE DESIGN TARGETING MPER: WALK TOWARDS THE SUN}

Despite many efforts, bNAbs targeting MPER still cannot be induced by immunization. Only a few vaccine candidates 
were found to induce neutralizing antibodies, albeit with low potency and limited breadth. Initially, bNAb-binding amino acid sequences were introduced into fusion proteins, peptide-based proteins or chimeric viruses, attempting to induce 2F5 or 4E10-like antibodies (Montero et al., 2008), but only MPER-specific antibodies with no neutralizing activity were produced. Therefore, beyond the recognition of specific peptidic sequences within MPER, additional variables should be considered. The common characteristics revealed by anti-MPER bNAbs, such as lipid reactivity (Frey et al., 2008; Alam et al., 2009), indicate that similar antibodies could be obtained by presenting MPER-based immunogens with a proper conformation in a membrane-like environment. Therefore, as shown in Fig. 3, when it comes to MPERbased vaccine design, at least two aspects should be considered: (1) which conformation would most likely induce anti-MPER bNAbs and (2) what role membrane lipids play in shaping the structure of MPER. The latter aspect suggests that the corresponding immunogen design should take into account accurate lipid components and adjuvant systems (Molinos-Albert et al., 2017b).

Recently, a B-cell lineage-based approach for vaccine design was developed progressively, but not yet applied to MPER (Soto et al., 2016; Bonsignori et al., 2017; Williams et al., 2017). Figure 3 is a schematic diagram representing a possible strategy to induce bNAbs against MPER on the basis of a comprehensive consideration of these two aspects. First, affinity-matured bNAbs and their precursors against MPER would be isolated from HIV-1-infected donors, using methods such as memory $B$ cell cultures or antigenspecific B cell sorting. Second, based on known bNAb sequences, next-generation sequencing could be used to retrieve numerous $V_{H} D J_{H}$ and $V_{L} J_{L}$ clonally related rearrangements. If appropriate longitudinal samples are available, it would be possible to define the full lineage phylogeny and infer the unmutated common ancestor (UCA) and early maturation intermediate antibodies (IAs). Third, recombinant monoclonal antibodies expressing the bNAb precursor $V_{H} D J_{H}$ and $V_{L} J_{L}$ rearrangements from UCA to IAs could then be used to design MPER-based immunogens. In light of studies on influenza vaccine development, it has been shown that bNAbs against the stem region of the HA could be induced by vaccinating animals with HA from different antigenic lineages (Ye et al., 2011). This approach may also be applied to overcome the weakness of low immunogenicity of MPER-based HIV vaccine. For example, cross primeboost immunizations with MPER antigens from different HIV1 subtypes may induce enhanced bNAb responses. ZollaPazner et al. have demonstrated that cross prime-boost immunizations with antigens containing six V1V2 sequences and nine scaffold proteins from different HIV-1 subtypes (B, $C, E)$ have induced bNAb responses against infection of HIV, SIV and SHIV (Zolla-Pazner et al., 2016). Furthermore, different kinds of immunogens, such as MPER-based peptide, lipids and VLPS or pseudoviruses may also be tested. MPER-based peptide should be properly combined with
Figure 3. Schematic diagram representing a possible strategy to induce bNAbs against MPER. First, affinitymatured, bNAbs and their precursors against MPER are isolated from HIV-1-infected donors, using methods such as memory B cell cultures or antigen-specific B cell sorting. Second, based on known bNAb sequences, next-generation sequencing can be used to retrieve numerous $V_{H} D J_{H}$ and $V_{L} J_{L}$ clonally related rearrangements. If appropriate longitudinal samples are available, it is possible to define the full lineage phylogeny and infer the unmutated common ancestor (UCA) and early maturation intermediate antibodies (IAs). Third, recombinant monoclonal antibodies expressing the bNAb precursor $V_{H} D J_{H}$ and $V_{L} J_{L}$ rearrangements from UCA to IAs can be used to design MPER-based immunogens. Different kinds of immunogens should be included, such as MPER-based peptide, lipids and VLPs or pseudoviruses. MPER-based peptide should be properly combined with lipids, thus potentially presenting a conformation capable of engaging $B$ cells and inducing neutralizing antibodies.

lipids to present an appropriate conformation capable of engaging $B$ cells and inducing neutralizing antibodies.

To address the problem of proper MPER conformation to induce bNAbs and the role of membrane lipids for immunogen design, corresponding explorations have already been carried out, as shown in Table 2. In recent years, other viral proteins, as a scaffold, or modified HIV-1 Env were used to explore the appropriate conformation of MPER capable of inducing neutralizing antibodies. For instance, Phogat et al. (2008) utilized S1 protein of hepatitis B virus (HBV) fused with MPER to immunize mice and rabbits. Although antiMPER antibodies were generated, antiserum did not present neutralizing activity. P15 of porcine endogenous retrovirus presents a structure similar to that of HIV-1 gp41. Accordingly, Strasz et al. (2014) replaced E1 and E2 of P15 with FPPR and MPER of HIV-1, respectively, and 2F5-like antibodies were elicited, albeit without neutralizing activity, after immunizing rats, guinea pigs and goats. However, Luo et al. (2006) also utilized P15 of porcine endogenous retrovirus to replace E2 region with MPER, and the antiserum could neutralize HIV pseudoviruses at 1:20. When it comes to modified HIV-1 Env, such as replacing the loop between NHR and CHR with 2F5 epitope directly (Vassell et al., 2015), replacing the loop with GGGGS sequence (Habte et al., 2015), or deleting the cleavage site of gp120 and gp41 and fusion peptide (Dennison et al., 2011), antibodies without neutralizing activity were all detected in different kinds of antisera immunized with these modified proteins. Banerjee et al. (2016) constructed a gp41-HR1-54Q immunogen which was expected to induce neutralizing antibodies by reducing the stability of $6-\mathrm{HB}$ to simulate gp41 fusion intermediate state. The serum from immunized rabbits also had MPER-specific antibodies, but without neutralizing activity. 


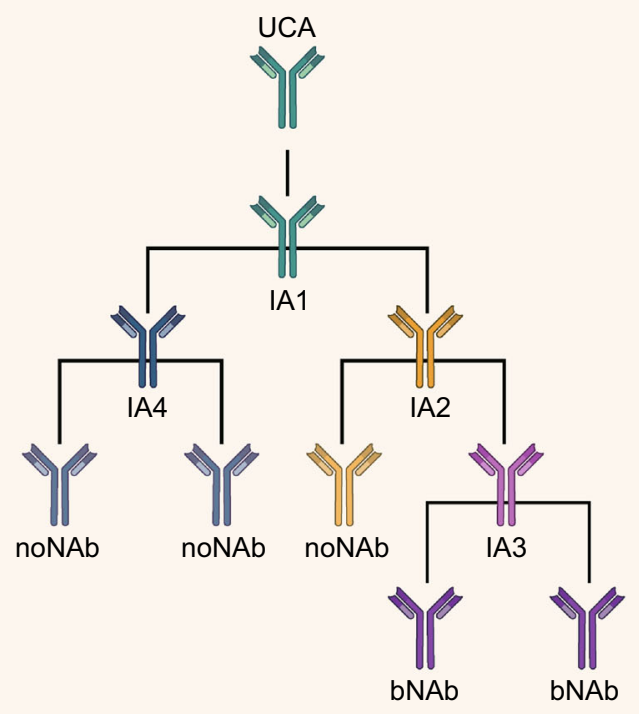

2. Map bnAb lineage phylogeny
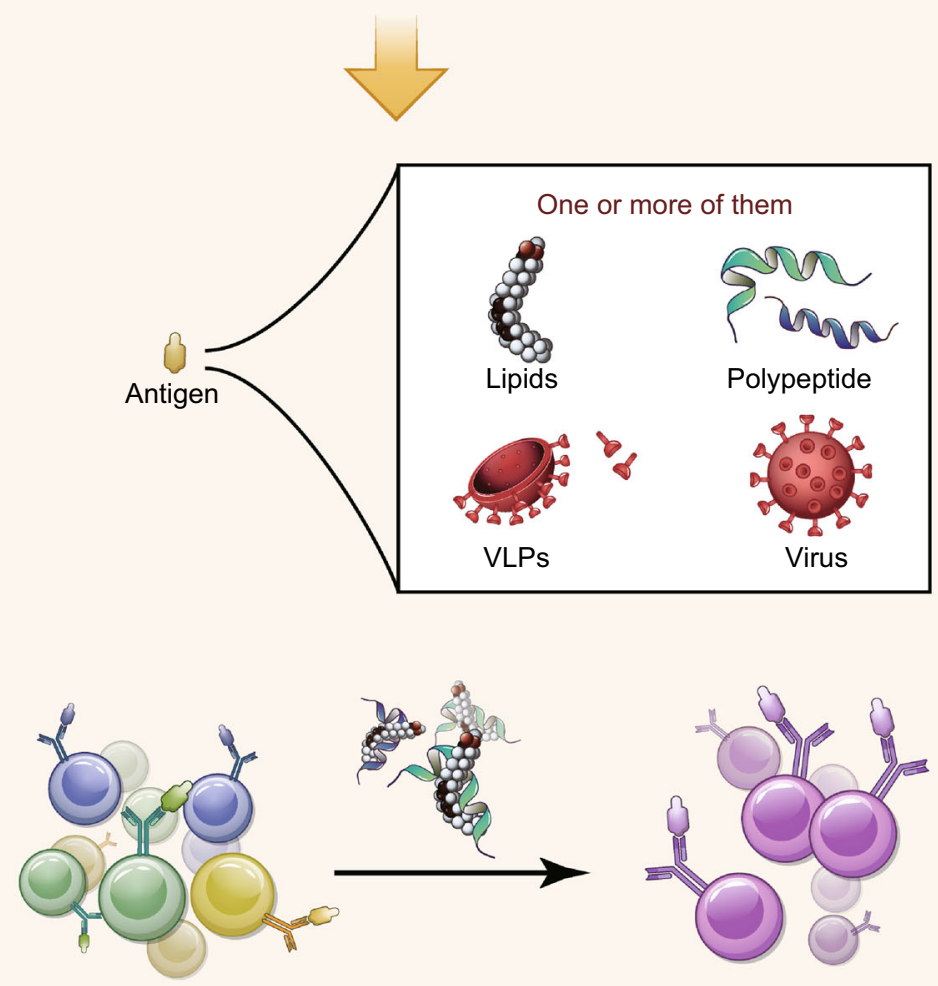

3. Design of immunogens

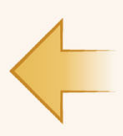

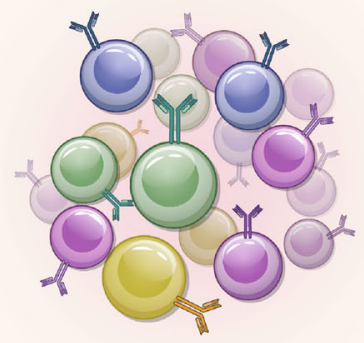

1. Isolate broadly neutralizing antibodies from memory B cells 
In general, the neutralizing activity of antibodies obtained by immunizing with protein scaffolds alone was unsatisfactory, possibly because other characteristics, such as membrane binding, were not addressed in the design of these scaffolds. Therefore, more and more research interest has focused on lipid-containing immunogens. Experimental data showed that membrane lipids may modulate the structure of MPER by promoting a native-like conformation, and such membrane lipids were demonstrated to improve immunogenicity (Hanson et al., 2015; Molinos-Albert et al., 2017a). In particular, it was proved that lipids overexpressed in the viral membrane, such as cholesterol and sphingomyelin, may induce higher antibody titers, compared with common POPC lipids (Molinos-Albert et al., 2017a).

In the lipid-containing immunogens, peptide-based vaccine regimens occupy a certain proportion. Matyas et al. (2009) utilized liposomes containing a synthetic MPER peptide as a peptide antigen, phosphatidylinositol-4-phosphate (PIP) as a lipid antigen, and monophosphoryl lipid A as a potent adjuvant to immunize mice. Anti-MPER and antiPIP antibodies were generated from which $\operatorname{lgM} \mathrm{mAb}$ was isolated that not only could recognize 2F5 and 4E10 epitopes and bind to PIP, but also could present a certain neutralizing capacity for HIV-1 virions in human peripheral blood. Venditto et al. (2014) synthesized the full-length MPER peptide and modified the single amino acid site of MPER chemically (phosphorylation, sulfation or nitrification). The modified peptide was presented in liposome to immunize rabbits. Higher titer antibodies were induced, but without neutralizing activity. Mohan et al. (2014) designed a liposome immunogen containing three tandem 2F5 epitope repeats and defensins to immunize mice intranasally. Antiserum and mucosal system of mice all generated high titer $\lg \mathrm{G}$ and IgM antibodies, and antiserum showed high neutralizing activity for an original isolate. Donius et al. used antigen-coupled liposome to immunize mice, and MPERspecific antibodies were isolated from the long-lived bone marrow plasma cells. These antibodies were produced under the selective pressure of MPER in the context of lipids, but they did not reveal any characteristic of polyreactivity (Donius et al., 2016).

Except for the peptide-based vaccine, chimeric viruses or virus-like particles (VLPs) may be better platforms as a result of taking the conformation of MPER peptide and the scaffold feature of lipids into consideration. With the research progresses in recent years, more viral vectors have been designed to express HIV-1 neutralizing epitope, such as adenovirus (Ura et al., 2009), influenza (Ye et al., 2011; Zang et al., 2015) and rhinovirus (Yi et al., 2013). These viral vectors can express and expose the chimeric peptidic epitopes and induce antibodies to some extent, but only a few of them could induce HIV-1 neutralizing antibodies. Ura et al. (2009) adopted adenovirus Ad5 as the vector and inserted 2F5 epitope sequence in the HVRS region of envelope protein. The antiserum of mice immunized with chimeric viruses could neutralize various strains of HIV-1. Moreover,
2F5-like antibodies were generated, and mAb targeting MPER was purified and verified. This $\mathrm{mAb}$ did, indeed, have the capacity to neutralize HIV-1. In view of the strong immunogenicity of influenza, Ye et al. (2011) fused HIV-1 gp41 at the C-terminus of influenza HA1 subunit and immunized new guinea pigs by HA/gp41 plasmid or VLPs. Anti-MPER antibodies were elicited, and antiserum could neutralize HIV pseudoviruses expressing SIV Env with chimeric 4E10 epitope. Such neutralizing capacity could also be blocked by the MPER peptide, indicating that the immunogen based on HA/gp41 produced anti-MPER antibodies with some neutralizing activity. Similarly, Zang et al. (2015) inserted 2F5 and 4E10 epitopes into the linker domain between the trimeric core structure and the transmembrane domain of influenza A virus HA2 and immunized guinea pigs with chimeric viruses. The serum exhibited a weak neutralizing activity for HIV-1 clade B and clade BC. Yi et al. (2013) utilized the rhinovirus as the vector to present the $2 \mathrm{~F} 5$ and $4 \mathrm{E} 10$ peptidic epitopes and immunized mice with human rhinovirus receptor hICAM-1. The antiserum could recognize and neutralize HIV-1. Meanwhile, it was shown that the existing anti-rhinovirus antibodies could be avoided by nasal immunization without influencing the presentation of antigen epitope on the rhinovirus vector.

To some extent, the titer and neutralizing activity of antibodies induced by chimeric viruses and VLPs are indeed superior to the protein vaccine and peptide-based vaccine, but bNAbs are still not elicited, as expected, to protect humans powerfully from HIV-1 infection. The complicated features of MPER, such as structure and immunology, still constitute the main stumbling blocks against the development of a successful vaccine.

\section{CONCLUSIONS AND PROSPECTS}

In conclusion, recent substantial progresses involving the analyses of structure and immunology of MPER, particularly, the structure of this region bound by three MPER-specific bNAbs (2F5, 4E10 and 10E8), their epitopes, and their neutralization mechanisms. However, no one can induce bNAbs targeting MPER by immunization, which, according to the most recent studies, can largely be attributed to two key problems. On the one hand, unknown conformations confound vaccine design against MPER. Neither native MPER conformation nor the conformation capable of inducing neutralizing antibodies has been precisely analyzed. Moreover, the allosteric mode of MPER during membrane fusion has not been demonstrated. On the other hand, investigators need to focus on the failure to induce antiMPER bNAbs in relation to the prevalence of autoreactivity/ polyreactivity, as shown by the reported MPER-specific bNAbs.

Meanwhile, we need to further probe the matter of protection relative to the sufficiency of antibody-dependent cellmediated cytotoxicity (ADCC) antibodies and the broader protection of bNAbs. Indeed, although bNAbs are crucial to 


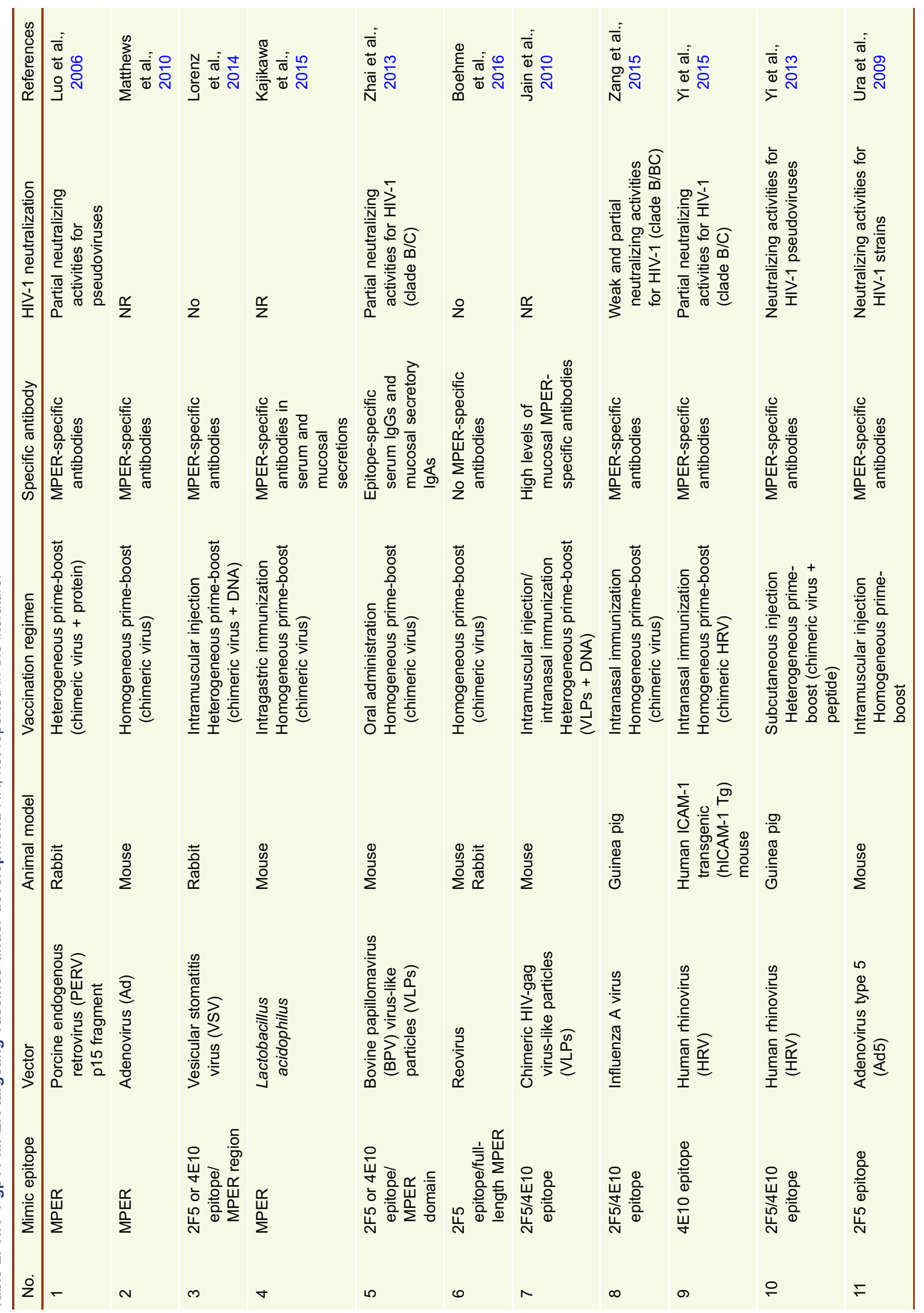




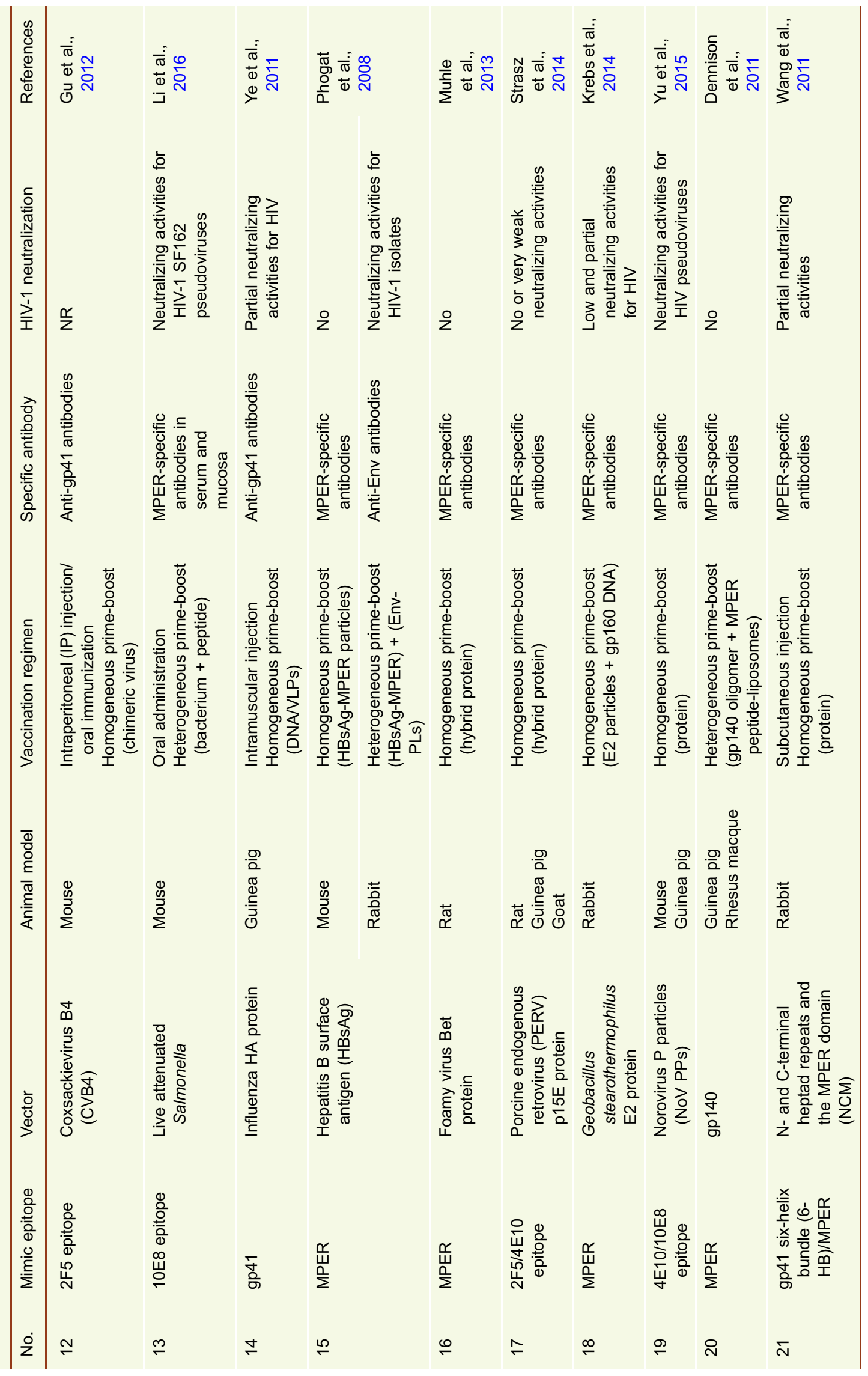




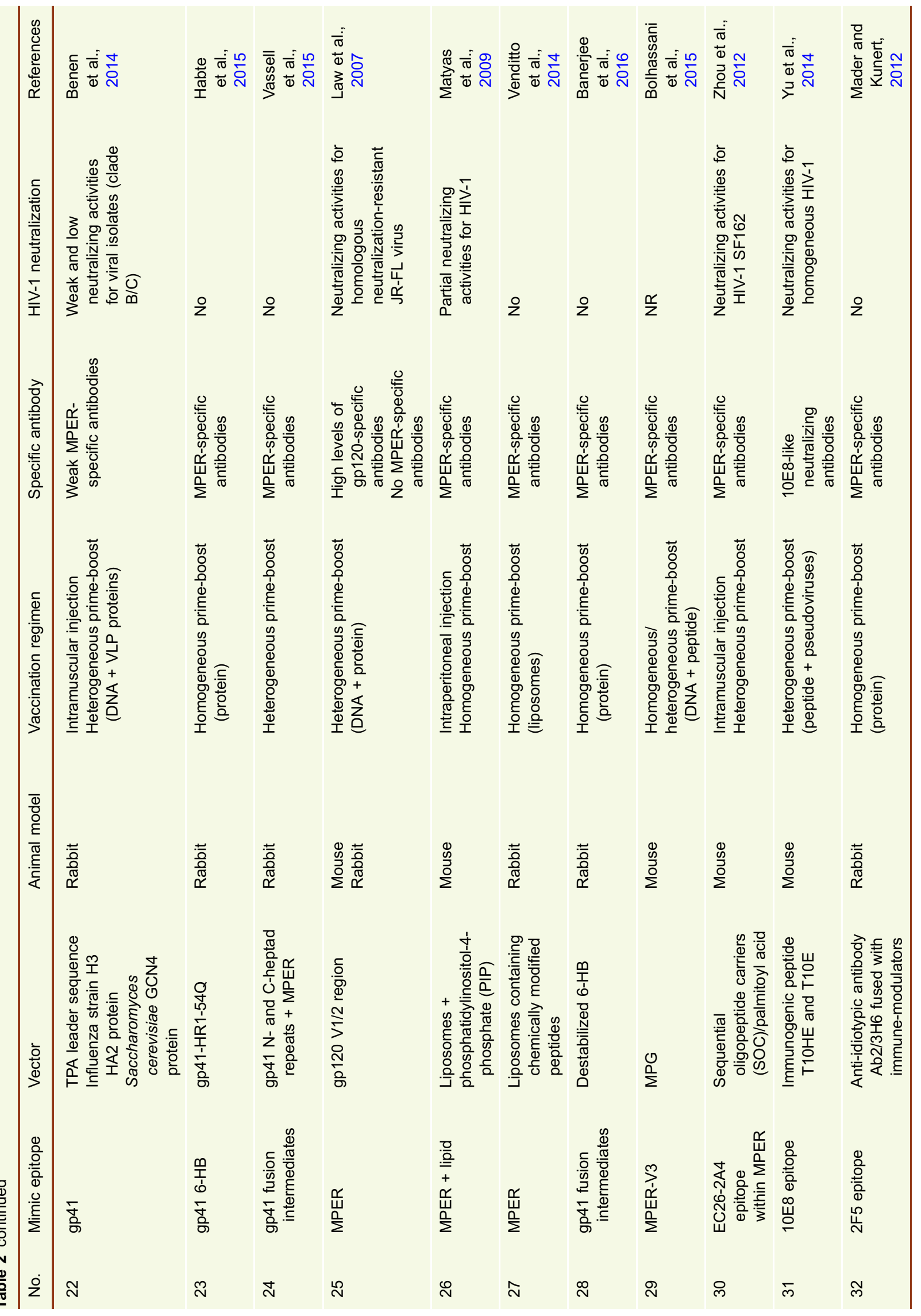




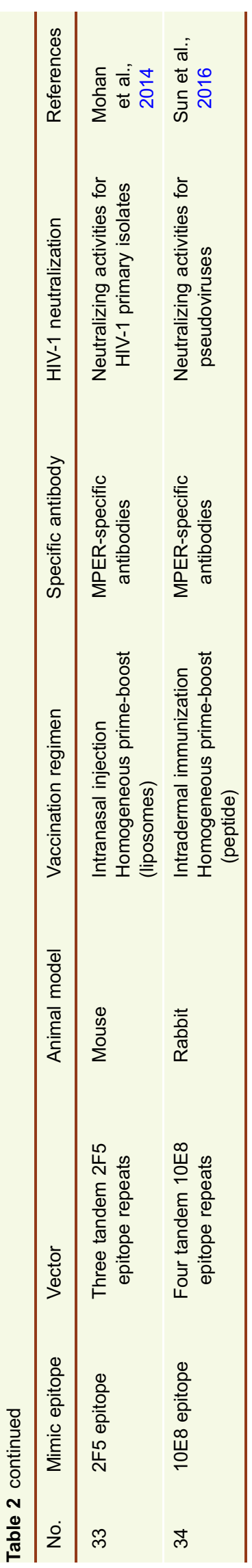

protect humans from HIV-1 infection, the role of non-neutralizing antibodies, especially ADCC antibodies, in protection has been revealed in some studies. As mentioned above, the protective effect of RV144 vaccine is related to ADCC antibodies, rather than neutralizing antibodies, implying that neutralizing antibodies may be not necessary. In another study, vaginal IgA with ADCC and transcytosisblocking activity induced by gp41-engrafted virions were closely related to the protection of NHP from SHIV infection (Bomsel et al., 2011). Recently, Sun et al. (2016) designed an immunogen containing four tandem 10E8 epitope repeats that exhibits $\alpha$-helical conformation and the key amino acids $\mathrm{W}$ and $\mathrm{F}$, which can point toward different directions when the long peptide binds the plasma membrane, thereby strengthening the induction of antibodies capable of binding to the native conformation of MPER on the viral envelope. After immunizing New Zealand rabbits with the immunogen, the ADCC reporter gene was activated, suggesting the existence of ADCC activity. However, the evaluation standard for protective effect of ADCC antibody was absent, leading to past neglect in the design and evaluation of an MPER-based vaccine.

In a word, the design of the MPER-based vaccine is replete with complications that require further elucidation; therefore, we still have a long way to go before the bNAbs dilemma, as detailed in this review, is settled. MPER, a conserved target, does, however, remain of vital interest, but apart from inducing neutralizing antibodies, non-neutralizing, yet protective, antibodies might be a future direction. Moreover, similar to "cocktail therapy", the induction of combinational protective antibodies targeting several regions, such as V1V2 and MPER, may be required to achieve the best protection. If this strategy is adopted, MPER is one target particularly worthy of consideration.

\section{ACKNOWLEDGEMENTS}

This work was supported by the National Natural Science Foundation of China (Grant Nos. 81661128041 and 81672019 to L. Lu; 81630090 to S. Jiang), Shanghai Rising-Star Program (16QA1400300) and Wuhan Science and Technology Project (2016060101010066). We also thank Guangzhou SageneBiotech Co., LTD for helping us draw pictures.

\section{ABBREVIATIONS}

ADCC, antibody-dependent cell-mediated cytotoxicity; AIDS, acquired immunodeficiency syndrome; bNAbs, broadly neutralizing antibodies; CDR, complementary determining region; CTLs, cytotoxic T lymphocytes; 6-HB, 6-helix bundle; KI, knock-in; HBV, hepatitis B virus; Env, envelope glycoprotein; FP, fusion peptide; HIV-1, human immunodeficiency virus type-1; HR1, heptad repeat 1; $\mathrm{HR} 2$, heptad repeat $1 ; I \mathrm{C}_{50}$, concentration causing $50 \%$ inhibition of the desired activity; mAbs, monoclonal antibodies; MPER, membrane-proximal external region; NMR, nuclear magnetic resonance; PIP, phosphatidylinositol-4-phosphate; SIV, simian immunodeficiency virus; SPR, surface plasmon resonance; TM, 
transmembrane; UCA, unmutated common ancestor; VLPS, viruslike particles.

\section{COMPLIANCE WITH ETHICS GUIDELINES}

Huan Liu, Xiaojie Su, Lulu Si, Lu Lu and Shibo Jiang declare that they have no conflict of interest. This article does not contain any studies with human or animal subjects performed by the any of the authors.

\section{OPEN ACCESS}

This article is distributed under the terms of the Creative Commons Attribution 4.0 International License (http://creativecommons.org/ licenses/by/4.0/), which permits unrestricted use, distribution, and reproduction in any medium, provided you give appropriate credit to the original author(s) and the source, provide a link to the Creative Commons license, and indicate if changes were made.

\section{REFERENCES}

Alam SM, McAdams M, Boren D, Rak M, Scearce RM, Gao F, Camacho ZT, Gewirth D, Kelsoe G, Chen P et al (2007) The role of antibody polyspecificity and lipid reactivity in binding of broadly neutralizing anti-HIV-1 envelope human monoclonal antibodies $2 \mathrm{~F} 5$ and $4 \mathrm{E} 10$ to glycoprotein 41 membrane proximal envelope epitopes. J Immunol 178:4424-4435

Alam SM, Morelli M, Dennison SM, Liao HX, Zhang R, Xia SM, RitsVolloch S, Sun L, Harrison SC, Haynes BF et al (2009) Role of HIV membrane in neutralization by two broadly neutralizing antibodies. Proc Natl Acad Sci USA 106:20234-20239

Alfsen A, Bomsel M (2002) HIV-1 gp41 envelope residues 650-685 exposed on native virus act as a lectin to bind epithelial cell galactosyl ceramide. J Biol Chem 277:25649-25659

Alfsen A, Iniguez P, Bouguyon E, Bomsel M (2001) Secretory IgA specific for a conserved epitope on gp41 envelope glycoprotein inhibits epithelial transcytosis of HIV-1. J Immunol 166:62576265

Banerjee S, Shi H, Habte HH, Qin Y, Cho MW (2016) Modulating immunogenic properties of HIV-1 gp41 membrane-proximal external region by destabilizing six-helix bundle structure. Virology 490:17-26

Barouch DH (2008) Challenges in the development of an HIV-1 vaccine. Nature 455:613-619

Bellamy-McIntyre AK, Lay CS, Baar S, Maerz AL, Talbo GH, Drummer HE, Poumbourios P (2007) Functional links between the fusion peptide-proximal polar segment and membraneproximal region of human immunodeficiency virus gp41 in distinct phases of membrane fusion. J Biol Chem 282:23104-23116

Benen TD, Tonks P, Kliche A, Kapzan R, Heeney JL, Wagner R (2014) Development and immunological assessment of VLPbased immunogens exposing the membrane-proximal region of the HIV-1 gp41 protein. J Biomed Sci 21:79

Binley JM, Wrin T, Korber B, Zwick MB, Wang M, Chappey C, Stiegler G, Kunert R, Zolla-Pazner S, Katinger H et al (2004)
Comprehensive cross-clade neutralization analysis of a panel of anti-human immunodeficiency virus type 1 monoclonal antibodies. J Virol 78:13232-13252

Blumenthal R, Durell S, Viard M (2012) HIV entry and envelope glycoprotein-mediated fusion. J Biol Chem 287:40841-40849

Boehme KW, Ikizler M, Iskarpatyoti JA, Wetzel JD, Willis J, Crowe JE Jr, LaBranche CC, Montefiori DC, Wilson GJ, Dermody TS (2016) Engineering recombinant reoviruses to display gp41 membrane-proximal external-region epitopes from HIV-1. mSphere. https://doi.org/10.1128/mSphere.00086-16

Bolhassani A, Kardani K, Vahabpour R, Habibzadeh N, Aghasadeghi MR, Sadat SM, Agi E (2015) Prime/boost immunization with HIV-1 MPER-V3 fusion construct enhances humoral and cellular immune responses. Immunology Letters 168:366-373

Bomsel M (1997) Transcytosis of infectious human immunodeficiency virus across a tight human epithelial cell line barrier. Nat Med 3:42-47

Bomsel M, Tudor D, Drillet AS, Alfsen A, Ganor Y, Roger MG, Mouz $\mathrm{N}$, Amacker M, Chalifour A, Diomede L et al (2011) Immunization with HIV-1 gp41 subunit virosomes induces mucosal antibodies protecting nonhuman primates against vaginal SHIV challenges. Immunity 34:269-280

Bonsignori M, Liao HX, Gao F, Williams WB, Alam SM, Montefiori DC, Haynes BF (2017) Antibody-virus co-evolution in HIV infection: paths for HIV vaccine development. Immunol Rev 275:145-160

Bryson S, Cunningham A, Ho J, Hynes RC, Isenman DE, Barber $\mathrm{BH}$, Kunert R, Katinger $\mathrm{H}$, Klein M, Pai EF (2001) Crossneutralizing human monoclonal anti-HIV-1 antibody 2F5: preparation and crystallographic analysis of the free and epitopecomplexed forms of its F-ab' fragment. Protein and Peptide Letters 8:413-418

Bryson S, Julien JP, Isenman DE, Kunert R, Katinger $H$, Pai EF (2008) Crystal structure of the complex between the $F(a b)$ ' fragment of the cross-neutralizing anti-HIV-1 antibody 2F5 and the $F(a b)$ fragment of its anti-idiotypic antibody $3 \mathrm{H} 6$. J Mol Biol 382:910-919

Buchacher A, Predl R, Strutzenberger K, Steinfellner W, Trkola A, Purtscher M, Gruber G, Tauer C, Steindl F, Jungbauer A et al (1994) Generation of human monoclonal antibodies against HIV1 proteins; electrofusion and Epstein-Barr virus transformation for peripheral blood lymphocyte immortalization. AIDS Res Hum Retrovir 10:359-369

Bures R, Morris L, Williamson C, Ramjee G, Deers M, Fiscus SA, Abdool-Karim S, Montefiori DC (2002) Regional clustering of shared neutralization determinants on primary isolates of clade $C$ human immunodeficiency virus type 1 from South Africa. J Virol 76:2233-2244

Buzon V, Natrajan G, Schibli D, Campelo F, Kozlov MM, Weissenhorn W (2010) Crystal structure of HIV-1 gp41 including both fusion peptide and membrane proximal external regions. PLoS Pathog 6:e1000880

Cardoso RM, Zwick MB, Stanfield RL, Kunert R, Binley JM, Katinger $H$, Burton DR, Wilson IA (2005) Broadly neutralizing anti-HIV antibody $4 \mathrm{E} 10$ recognizes a helical conformation of a highly conserved fusion-associated motif in gp41. Immunity 22:163-173 
Cardoso RM, Brunel FM, Ferguson S, Zwick M, Burton DR, Dawson PE, Wilson IA (2007) Structural basis of enhanced binding of extended and helically constrained peptide epitopes of the broadly neutralizing HIV-1 antibody 4E10. J Mol Biol 365:15331544

Chan DC, Kim PS (1998) HIV entry and its inhibition. Cell 93:681684

Chen J, Frey G, Peng H, Rits-Volloch S, Garrity J, Seaman MS, Chen B (2014) Mechanism of HIV-1 neutralization by antibodies targeting a membrane-proximal region of gp41. J Virol 88:12491258

Dennison SM, Stewart SM, Stempel KC, Liao HX, Haynes BF, Alam SM (2009) Stable docking of neutralizing human immunodeficiency virus type $1 \mathrm{gp} 41$ membrane-proximal external region monoclonal antibodies $2 \mathrm{~F} 5$ and $4 \mathrm{E} 10$ is dependent on the membrane immersion depth of their epitope regions. J Virol 83:10211-10223

Dennison SM, Sutherland LL, Jaeger FH, Anasti KM, Parks R, Stewart S, Bowman C, Xia SM, Zhang R, Shen X et al (2011) Induction of antibodies in rhesus macaques that recognize a fusion-intermediate conformation of HIV-1 gp41. PLoS ONE 6: e27824

Dev J, Park D, Fu Q, Chen J, Ha HJ, Ghantous F, Herrmann T, Chang W, Liu Z, Frey G et al (2016) Structural basis for membrane anchoring of HIV-1 envelope spike. Science 353:172175

Dimitrov AS, Jacobs A, Finnegan CM, Stiegler G, Katinger $H$, Blumenthal R (2007) Exposure of the membrane-proximal external region of HIV-1 gp41 in the course of HIV-1 envelope glycoprotein-mediated fusion. Biochemistry 46:1398-1401

Donius LR, Cheng Y, Choi J, Sun ZY, Hanson M, Zhang M, Gierahn TM, Marquez S, Uduman M, Kleinstein SH et al (2016) Generation of long-lived bone marrow plasma cells secreting antibodies specific for the HIV-1 gp41 membrane-proximal external region in the absence of polyreactivity. J Virol 90:8875-8890

Doria-Rose NA, Klein RM, Manion MM, O'Dell S, Phogat A, Chakrabarti B, Hallahan CW, Migueles SA, Wrammert J, Ahmed $R$ et al (2009) Frequency and phenotype of human immunodeficiency virus envelope-specific $B$ cells from patients with broadly cross-neutralizing antibodies. J Virol 83:188-199

Doyle-Cooper C, Hudson KE, Cooper AB, Ota T, Skog P, Dawson PE, Zwick MB, Schief WR, Burton DR, Nemazee D (2013) Immune tolerance negatively regulates $B$ cells in knock-in mice expressing broadly neutralizing HIV antibody 4E10. J Immunol 191:3186-3191

Fauci AS, Johnston MI, Dieffenbach CW, Burton DR, Hammer SM et al (2008) HIV vaccine research: the way forward. Science 321:530-532

Frey G, Peng H, Rits-Volloch S, Morelli M, Cheng Y, Chen B (2008) A fusion-intermediate state of HIV-1 gp41 targeted by broadly neutralizing antibodies. Proc Natl Acad Sci USA 105:3739-3744

Gray ES, Meyers T, Gray G, Montefiori DC, Morris L (2006) Insensitivity of paediatric HIV-1 subtype $C$ viruses to broadly neutralising monoclonal antibodies raised against subtype $B$. PLoS Med 3:e255

Gray ES, Taylor N, Wycuff D, Moore PL, Tomaras GD, Wibmer CK, Puren A, DeCamp A, Gilbert PB, Wood B et al (2009) Antibody specificities associated with neutralization breadth in plasma from human immunodeficiency virus type 1 subtype C-infected blood donors. J Virol 83:8925-8937

Gu R, Stagnar C, Zaichenko L, Ramsingh Al (2012) Induction of mucosal HIV-specific B and T cell responses after oral immunization with live coxsackievirus B4 recombinants. Vaccine 30:3666-3674

Habte HH, Banerjee S, Shi H, Qin Y, Cho MW (2015) Immunogenic properties of a trimeric gp41-based immunogen containing an exposed membrane-proximal external region. Virology 486:187197

Hanson MC, Abraham W, Crespo MP, Chen SH, Liu H, Szeto GL, Kim M, Reinherz EL, Irvine DJ (2015) Liposomal vaccines incorporating molecular adjuvants and intrastructural T-cell help promote the immunogenicity of HIV membrane-proximal external region peptides. Vaccine 33:861-868

Haynes BF, Mascola JR (2017) The quest for an antibody-based HIV vaccine. Immunol Rev 275:5-10

Haynes BF, Fleming J, St Clair EW, Katinger H, Stiegler G, Kunert R, Robinson J, Scearce RM, Plonk K, Staats HF et al (2005a) Cardiolipin polyspecific autoreactivity in two broadly neutralizing HIV-1 antibodies. Science 308:1906-1908

Haynes BF, Moody MA, Verkoczy L, Kelsoe G, Alam SM (2005b) Antibody polyspecificity and neutralization of HIV-1: a hypothesis. Hum Antib 14:59-67

Hessell AJ, Rakasz EG, Tehrani DM, Huber M, Weisgrau KL, Landucci G, Forthal DN, Koff WC, Poignard P, Watkins DI et al (2010) Broadly neutralizing monoclonal antibodies 2F5 and 4E10 directed against the human immunodeficiency virus type $1 \mathrm{gp} 41$ membrane-proximal external region protect against mucosal challenge by simian-human immunodeficiency virus SHIVBa-L. J Virol 84:1302-1313

Huang J, Ofek G, Laub L, Louder MK, Doria-Rose NA, Longo NS, Imamichi H, Bailer RT, Chakrabarti B, Sharma SK et al (2012) Broad and potent neutralization of HIV-1 by a gp41-specific human antibody. Nature 491:406-412

Huarte N, Lorizate M, Maeso R, Kunert R, Arranz R, Valpuesta JM, Nieva JL (2008) The broadly neutralizing anti-human immunodeficiency virus type $14 \mathrm{E} 10$ monoclonal antibody is better adapted to membrane-bound epitope recognition and blocking than 2F5. J Virol 82:8986-8996

Irimia A, Sarkar A, Stanfield RL, Wilson IA (2016) Crystallographic identification of lipid as an integral component of the epitope of HIV broadly neutralizing antibody 4E10. Immunity 44:21-31

Irimia A, Serra AM, Sarkar A, Jacak R, Kalyuzhniy O, Sok D, SayeFrancisco KL, Schiffner T, Tingle R, Kubitz M et al (2017) Lipid interactions and angle of approach to the HIV-1 viral membrane of broadly neutralizing antibody 10E8: Insights for vaccine and therapeutic design. PLoS Pathog 13:e1006212

Jain S, Patrick AJ, Rosenthal KL (2010) Multiple tandem copies of conserved gp41 epitopes incorporated in gag virus-like particles elicit systemic and mucosal antibodies in an optimized heterologous vector delivery regimen. Vaccine 28:7070-7080

Julien JP, Bryson S, Nieva JL, Pai EF (2008) Structural details of HIV-1 recognition by the broadly neutralizing monoclonal antibody 2F5: epitope conformation, antigen-recognition loop mobility, and anion-binding site. J Mol Biol 384:377-392 
Kajikawa A, Zhang L, LaVoy A, Bumgardner S, Klaenhammer TR, Dean GA (2015) Mucosal immunogenicity of genetically modified lactobacillus acidophilus expressing an HIV-1 epitope within the surface layer protein. PLoS ONE 10:e0141713

Kelsoe G, Haynes BF (2017) Host controls of HIV broadly neutralizing antibody development. Immunol Rev 275:79-88

Kim M, Song L, Moon J, Sun ZY, Bershteyn A, Hanson M, Cain D, Goka S, Kelsoe G, Wagner G et al (2013) Immunogenicity of membrane-bound HIV-1 gp41 membrane-proximal external region (MPER) segments is dominated by residue accessibility and modulated by stereochemistry. J Biol Chem 288:3188831901

Kim AS, Leaman DP, Zwick MB (2014) Antibody to gp41 MPER alters functional properties of HIV-1 Env without complete neutralization. PLoS Pathog 10:e1004271

Kim JH, Excler JL, Michael NL (2015) Lessons from the RV144 Thai phase III HIV-1 vaccine trial and the search for correlates of protection. Annu Rev Med 66:423-437

Klasse PJ (2012) The molecular basis of HIV entry. Cell Microbiol 14:1183-1192

Krebs SJ, McBurney SP, Kovarik DN, Waddell CD, Jaworski JP, Sutton WF, Gomes MM, Trovato M, Waagmeester G, Barnett SJ et al (2014) Multimeric scaffolds displaying the HIV-1 envelope MPER induce MPER-specific antibodies and cross-neutralizing antibodies when co-immunized with gp160 DNA. PLoS ONE 9: e113463

Landais E, Huang X, Havenar-Daughton C, Murrell B, Price MA, Wickramasinghe L, Ramos A, Bian CB, Simek M, Allen S et al (2016) Broadly neutralizing antibody responses in a large longitudinal sub-Saharan HIV primary infection cohort. PLoS Pathog 12:e1005369

Law M, Cardoso RM, Wilson IA, Burton DR (2007) Antigenic and immunogenic study of membrane-proximal external regiongrafted gp120 antigens by a DNA prime-protein boost immunization strategy. J Virol 81:4272-4285

Lee JH, Ozorowski G, Ward AB (2016) Cryo-EM structure of a native, fully glycosylated, cleaved HIV-1 envelope trimer. Science 351:1043-1048

Leroux-Roels G, Maes C, Clement F, van Engelenburg F, van den Dobbelsteen M, Adler M, Amacker M, Lopalco L, Bomsel M, Chalifour A et al (2013) Randomized phase I: safety, immunogenicity and mucosal antiviral activity in young healthy women vaccinated with HIV-1 Gp41 P1 peptide on virosomes. PLoS ONE 8:e55438

Li QH, Jin G, Wang JY, Li HN, Liu H, Chang XY, Wang FX, Liu SL (2016) Live attenuated Salmonella displaying HIV-1 10E8 epitope on fimbriae: systemic and mucosal immune responses in BALB/C mice by mucosal administration. Sci Rep 6:29556

Liu J, Bartesaghi A, Borgnia MJ, Sapiro G, Subramaniam S (2008) Molecular architecture of native HIV-1 gp120 trimers. Nature 455:109-113

Liu M, Yang G, Wiehe K, Nicely NI, Vandergrift NA, Rountree W, Bonsignori M, Alam SM, Gao J, Haynes BF et al (2015) Polyreactivity and autoreactivity among HIV-1 antibodies. J Virol 89:784-798

Lorenz IC, Nguyen HT, Kemelman M, Lindsay RW, Yuan M, Wright KJ, Arendt H, Back JW, DeStefano J, Hoffenberg S et al (2014)
The stem of vesicular stomatitis virus $G$ can be replaced with the HIV-1 Env membrane-proximal external region without loss of $G$ function or membrane-proximal external region antigenic properties. AIDS Res Hum Retrovir 30:1130-1144

Louder MK, Sambor A, Chertova E, Hunte T, Barrett S, Ojong F, Sanders-Buell E, Zolla-Pazner S, McCutchan FE, Roser JD et al (2005) HIV-1 envelope pseudotyped viral vectors and infectious molecular clones expressing the same envelope glycoprotein have a similar neutralization phenotype, but culture in peripheral blood mononuclear cells is associated with decreased neutralization sensitivity. Virology 339:226-238

Luo M, Yuan F, Liu Y, Jiang S, Song X, Jiang P, Yin X, Ding M, Deng $H$ (2006) Induction of neutralizing antibody against human immunodeficiency virus type 1 (HIV-1) by immunization with gp41 membrane-proximal external region (MPER) fused with porcine endogenous retrovirus (PERV) p15E fragment. Vaccine 24:435-442

Lutje Hulsik D, Liu YY, Strokappe NM, Battella S, El Khattabi M, McCoy LE, Sabin C, Hinz A, Hock M, Macheboeuf P et al (2013) A gp41 MPER-specific llama VHH requires a hydrophobic CDR3 for neutralization but not for antigen recognition. PLoS Pathog 9: e1003202

Maddon PJ, Dalgleish AG, McDougal JS, Clapham PR, Weiss RA, Axel R (1986) The T4 gene encodes the AIDS virus receptor and is expressed in the immune system and the brain. Cell 47:333348

Mader A, Kunert R (2012) Evaluation of the potency of the antiidiotypic antibody Ab2/3H6 mimicking gp41 as an HIV-1 vaccine in a rabbit prime/boost study. PLoS ONE 7:e39063

Mascola JR, Stiegler G, VanCott TC, Katinger H, Carpenter CB, Hanson CE, Beary H, Hayes D, Frankel SS, Birx DL et al (2000) Protection of macaques against vaginal transmission of a pathogenic HIV-1/SIV chimeric virus by passive infusion of neutralizing antibodies. Nat Med 6:207-210

Matthews QL, Fatima A, Tang Y, Perry BA, Tsuruta Y, Komarova S, Timares L, Zhao C, Makarova N, Borovjagin AV et al (2010) HIV antigen incorporation within adenovirus hexon hypervariable 2 for a novel HIV vaccine approach. PLoS ONE 5:e11815

Matyas GR, Wieczorek L, Beck Z, Ochsenbauer-Jambor C, Kappes JC, Michael NL, Polonis VR, Alving CR (2009) Neutralizing antibodies induced by liposomal HIV-1 glycoprotein 41 peptide simultaneously bind to both the $2 \mathrm{~F} 5$ or $4 \mathrm{E} 10$ epitope and lipid epitopes. AIDS 23:2069-2077

McDougal JS, Maddon PJ, Dalgleish AG, Clapham PR, Littman DR, Godfrey M, Maddon DE, Chess L, Weiss RA, Axel R (1986) The T4 glycoprotein is a cell-surface receptor for the AIDS virus. Cold Spring Harb Symp Quant Biol 51(Pt 2):703-711

Medlock J, Pandey A, Parpia AS, Tang A, Skrip LA, Galvani AP (2017) Effectiveness of UNAIDS targets and HIV vaccination across 127 countries. Proc Natl Acad Sci USA 114:4017-4022

Miedema F (2008) A brief history of HIV vaccine research: stepping back to the drawing board? AIDS 22:1699-1703

Miglietta R, Pastori C, Venuti A, Ochsenbauer C, Lopalco L (2014) Synergy in monoclonal antibody neutralization of HIV-1 pseudoviruses and infectious molecular clones. J Transl Med 12:346

Mohan T, Verma P, Rao DN (2014) Comparative mucosal immunogenicity of HIV gp41 membrane-proximal external region (MPER) 
containing single and multiple repeats of ELDKWA sequence with defensin peptides. Immunobiology 219:292-301

Molinos-Albert LM, Bilbao E, Agullo L, Marfil S, Garcia E, Rodriguez de la Concepcion ML, Izquierdo-Useros N, Vilaplana C, NietoGarai JA, Contreras FX et al (2017a) Proteoliposomal formulations of an HIV-1 gp41-based miniprotein elicit a lipid-dependent immunodominant response overlapping the 2F5 binding motif. Sci Rep 7:40800

Molinos-Albert LM, Clotet B, Blanco J, Carrillo J (2017b) Immunologic insights on the membrane proximal external region: a major human immunodeficiency virus type-1 vaccine target. Front Immunol 8:1154

Montero M, van Houten NE, Wang X, Scott JK (2008) The membrane-proximal external region of the human immunodeficiency virus type 1 envelope: dominant site of antibody neutralization and target for vaccine design. Microbiol Mol Biol Rev 72:54-84

Morris L, Chen X, Alam M, Tomaras G, Zhang R, Marshall DJ, Chen B, Parks R, Foulger A, Jaeger F et al (2011) Isolation of a human anti-HIV gp41 membrane proximal region neutralizing antibody by antigen-specific single B cell sorting. PLoS ONE 6:e23532

Muhle M, Hoffmann K, Lochelt M, Denner J (2013) Immunisation with foamy virus Bet fusion proteins as novel strategy for HIV-1 epitope delivery. Immunol Res 56:61-72

Munoz-Barroso I, Salzwedel K, Hunter E, Blumenthal R (1999) Role of the membrane-proximal domain in the initial stages of human immunodeficiency virus type 1 envelope glycoprotein-mediated membrane fusion. J Virol 73:6089-6092

Muster T, Steindl F, Purtscher M, Trkola A, Klima A, Himmler G, Ruker F, Katinger H (1993) A conserved neutralizing epitope on gp41 of human immunodeficiency virus type 1. J Virol 67:66426647

Muster T, Guinea R, Trkola A, Purtscher M, Klima A, Steindl F, Palese P, Katinger H (1994) Cross-neutralizing activity against divergent human immunodeficiency virus type 1 isolates induced by the gp41 sequence ELDKWAS. J Virol 68:4031-4034

Nelson JD, Brunel FM, Jensen R, Crooks ET, Cardoso RM, Wang M, Hessell A, Wilson IA, Binley JM, Dawson PE et al (2007) An affinity-enhanced neutralizing antibody against the membraneproximal external region of human immunodeficiency virus type 1 gp41 recognizes an epitope between those of 2F5 and 4E10. J Virol 81:4033-4043

Nemazee D (2017) Mechanisms of central tolerance for B cells. Nat Rev Immunol 17:281-294

Ofek G, Tang M, Sambor A, Katinger H, Mascola JR, Wyatt R, Kwong PD (2004) Structure and mechanistic analysis of the antihuman immunodeficiency virus type 1 antibody 2F5 in complex with its gp41 epitope. J Virol 78:10724-10737

Ofek G, Zirkle B, Yang Y, Zhu Z, McKee K, Zhang B, Chuang GY, Georgiev IS, O'Dell S, Doria-Rose N et al (2014) Structural basis for HIV-1 neutralization by 2F5-like antibodies m66 and m66.6. J Virol 88:2426-2441

Pegu A, Yang ZY, Boyington JC, Wu L, Ko SY, Schmidt SD, McKee K, Kong WP, Shi W, Chen $X$ et al (2014) Neutralizing antibodies to HIV-1 envelope protect more effectively in vivo than those to the CD4 receptor. Sci Transl Med. https://doi.org/10.1126/ scitransImed.3008992
Phogat S, Svehla K, Tang M, Spadaccini A, Muller J, Mascola J, Berkower I, Wyatt R (2008) Analysis of the human immunodeficiency virus type $1 \mathrm{gp} 41$ membrane proximal external region arrayed on hepatitis B surface antigen particles. Virology 373:7284

Provine NM, Puryear WB, Wu X, Overbaugh J, Haigwood NL (2009) The infectious molecular clone and pseudotyped virus models of human immunodeficiency virus type 1 exhibit significant differences in virion composition with only moderate differences in infectivity and inhibition sensitivity. J Virol 83:9002-9007

Provine NM, Cortez V, Chohan V, Overbaugh J (2012) The neutralization sensitivity of viruses representing human immunodeficiency virus type 1 variants of diverse subtypes from early in infection is dependent on producer cell, as well as characteristics of the specific antibody and envelope variant. Virology 427:25-33

Rizzuto CD, Wyatt R, Hernandez-Ramos N, Sun Y, Kwong PD, Hendrickson WA, Sodroski J (1998) A conserved HIV gp120 glycoprotein structure involved in chemokine receptor binding. Science 280:1949-1953

Salzwedel K, West JT, Hunter E (1999) A conserved tryptophan-rich motif in the membrane-proximal region of the human immunodeficiency virus type 1 gp41 ectodomain is important for Envmediated fusion and virus infectivity. J Virol 73:2469-2480

Scheid JF, Mouquet H, Feldhahn N, Seaman MS, Velinzon K, Pietzsch J, Ott RG, Anthony RM, Zebroski H, Hurley A et al (2009) Broad diversity of neutralizing antibodies isolated from memory B cells in HIV-infected individuals. Nature 458:636-640

Song L, Sun ZY, Coleman KE, Zwick MB, Gach JS, Wang JH, Reinherz EL, Wagner G, Kim M (2009) Broadly neutralizing antiHIV-1 antibodies disrupt a hinge-related function of gp41 at the membrane interface. Proc Natl Acad Sci USA 106:9057-9062

Soto C, Ofek G, Joyce MG, Zhang B, McKee K, Longo NS, Yang Y, Huang J, Parks R, Eudailey J et al (2016) Developmental pathway of the MPER-directed HIV-1-neutralizing antibody $10 \mathrm{E} 8$. PLoS ONE 11:e0157409

Stano P, Bufali S, Domazou AS, Luisi PL (2005) Effect of tryptophan oligopeptides on the size distribution of POPC liposomes: a dynamic light scattering and turbidimetric study. J Liposome Res 15:29-47

Stiegler G, Kunert R, Purtscher M, Wolbank S, Voglauer R, Steindl F, Katinger $H$ (2001) A potent cross-clade neutralizing human monoclonal antibody against a novel epitope on gp41 of human immunodeficiency virus type 1. AIDS Res Hum Retrovir 17:17571765

Strasz N, Morozov VA, Kreutzberger J, Keller M, Eschricht M, Denner J (2014) Immunization with hybrid proteins containing the membrane proximal external region of HIV-1. AIDS Res Hum Retrovir 30:498-508

Su S, Wang Q, Xu W, Yu F, Hua C, Zhu Y, Jiang S, Lu L (2017a) A novel HIV-1 gp41 tripartite model for rational design of HIV-1 fusion inhibitors with improved antiviral activity. AIDS 31:885-894

Su S, Zhu Y, Ye S, Qi Q, Xia S, Ma Z, Yu F, Wang Q, Zhang R, Jiang $S$ et al (2017b) Creating an artificial tail anchor as a novel strategy to enhance the potency of peptide-based HIV fusion inhibitors. J Virol. https://doi.org/10.1128/JVI.01445-16

Suarez T, Gallaher WR, Agirre A, Goni FM, Nieva JL (2000a) Membrane interface-interacting sequences within the ectodomain 
of the human immunodeficiency virus type 1 envelope glycoprotein: putative role during viral fusion. J Virol 74:8038-8047

Suarez T, Nir S, Goni FM, Saez-Cirion A, Nieva JL (2000b) The pretransmembrane region of the human immunodeficiency virus type-1 glycoprotein: a novel fusogenic sequence. FEBS Lett 477:145-149

Subramaniam S (2006) The SIV surface spike imaged by electron tomography: one leg or three? PLoS Pathog 2:e91

Sun ZY, Oh KJ, Kim M, Yu J, Brusic V, Song L, Qiao Z, Wang JH, Wagner G, Reinherz EL (2008) HIV-1 broadly neutralizing antibody extracts its epitope from a kinked gp41 ectodomain region on the viral membrane. Immunity 28:52-63

Sun Z, Zhu Y, Wang Q, Ye L, Dai Y, Su S, Yu F, Ying T, Yang C, Jiang $S$ et al (2016) An immunogen containing four tandem 10E8 epitope repeats with exposed key residues induces antibodies that neutralize HIV-1 and activates an ADCC reporter gene. Emerg Microbes Infect 5:e65

Trkola A, Kuster H, Rusert P, Joos B, Fischer M, Leemann C, Manrique A, Huber M, Rehr M, Oxenius A et al (2005) Delay of HIV-1 rebound after cessation of antiretroviral therapy through passive transfer of human neutralizing antibodies. Nat Med 11:615-622

Ura T, Yoshida A, Xin KQ, Yoshizaki S, Yashima S, Abe S, Mizuguchi H, Okuda K (2009) Designed recombinant adenovirus type 5 vector induced envelope-specific CD8(+) cytotoxic T lymphocytes and cross-reactive neutralizing antibodies against human immunodeficiency virus type 1. J Gene Med 11:139-149

Vassell R, He Y, Vennakalanti P, Dey AK, Zhuang M, Wang W, Sun Y, Biron-Sorek Z, Srivastava IK, LaBranche CC et al (2015) Immunogens modeling a fusion-intermediate conformation of gp41 elicit antibodies to the membrane proximal external region of the HIV envelope glycoprotein. PLoS ONE 10:e0128562

Venditto VJ, Wieczorek L, Molnar S, Teque F, Landucci G, Watson DS, Forthal D, Polonis VR, Levy JA, Szoka FC Jr (2014) Chemically modified peptides based on the membrane-proximal external region of the HIV-1 envelope induce high-titer, epitopespecific nonneutralizing antibodies in rabbits. Clin Vaccine Immunol 21:1086-1093

Verkoczy L, Diaz M (2014) Autoreactivity in HIV-1 broadly neutralizing antibodies: implications for their function and induction by vaccination. Curr Opin HIV AIDS 9:224-234

Verkoczy L, Diaz M, Holl TM, Ouyang YB, Bouton-Verville H, Alam SM, Liao HX, Kelsoe G, Haynes BF (2010) Autoreactivity in an HIV-1 broadly reactive neutralizing antibody variable region heavy chain induces immunologic tolerance. Proc Natl Acad Sci USA 107:181-186

Verkoczy L, Chen Y, Bouton-Verville H, Zhang J, Diaz M, Hutchinson J, Ouyang YB, Alam SM, Holl TM, Hwang KK et al (2011) Rescue of HIV-1 broad neutralizing antibody-expressing B cells in $2 \mathrm{~F} 5 \mathrm{VH}$ $x$ VL knockin mice reveals multiple tolerance controls. J Immunol 187:3785-3797

Verkoczy L, Chen Y, Zhang J, Bouton-Verville H, Newman A, Lockwood B, Scearce RM, Montefiori DC, Dennison SM, Xia SM et al (2013) Induction of HIV-1 broad neutralizing antibodies in 2F5 knock-in mice: selection against membrane proximal external region-associated autoreactivity limits T-dependent responses. J Immunol 191:2538-2550
Verkoczy L, Kelsoe G, Haynes BF (2014) HIV-1 envelope gp41 broadly neutralizing antibodies: hurdles for vaccine development. PLoS Pathog 10:e1004073

Vishwanathan SA, Hunter E (2008) Importance of the membraneperturbing properties of the membrane-proximal external region of human immunodeficiency virus type $1 \mathrm{gp} 41$ to viral fusion. J Virol 82:5118-5126

von Boehmer H, Melchers F (2010) Checkpoints in lymphocyte development and autoimmune disease. Nat Immunol 11:14-20

Walker BD, Burton DR (2008) Toward an AIDS vaccine. Science 320:760-764

Walker LM, Phogat SK, Chan-Hui PY, Wagner D, Phung P, Goss JL, Wrin T, Simek MD, Fling S, Mitcham JL et al (2009) Broad and potent neutralizing antibodies from an African donor reveal a new HIV-1 vaccine target. Science 326:285-289

Wang J, Tong P, Lu L, Zhou L, Xu L, Jiang S, Chen YH (2011) HIV-1 gp41 core with exposed membrane-proximal external region inducing broad HIV-1 neutralizing antibodies. PLoS ONE 6: e18233

Wang Q, Dai Y, Sun Z, Su X, Yu Y, Hua C, Xu W, Jiang S, Lu L (2017) HIV-1 Env DNA prime plus gp120 and gp70-V1V2 boosts induce high level of V1V2-specific IgG and ADCC responses and low level of Env-specific IgA response: implication for improving RV144 vaccine regimen. Emerg Microbes Infect 6:e102

West AP Jr, Scharf L, Scheid JF, Klein F, Bjorkman PJ, Nussenzweig MC (2014) Structural insights on the role of antibodies in HIV-1 vaccine and therapy. Cell 156:633-648

Williams LD, Ofek G, Schatzle S, McDaniel JR, Lu X, Nicely NI, Wu L, Lougheed CS, Bradley T, Louder MK et al (2017) Potent and broad HIV-neutralizing antibodies in memory B cells and plasma. Sci Immunol. https://doi.org/10.1126/sciimmunol.aal2200

Wu L, Zhou T, Yang ZY, Svehla K, O'Dell S, Louder MK, Xu L, Mascola JR, Burton DR, Hoxie JA et al (2009) Enhanced exposure of the CD4-binding site to neutralizing antibodies by structural design of a membrane-anchored human immunodeficiency virus type 1 gp120 domain. J Virol 83:5077-5086

Wu X, Yang ZY, Li Y, Hogerkorp CM, Schief WR, Seaman MS, Zhou T, Schmidt SD, Wu L, Xu L et al (2010) Rational design of envelope identifies broadly neutralizing human monoclonal antibodies to HIV-1. Science 329:856-861

Wyatt R, Kwong PD, Desjardins E, Sweet RW, Robinson J, Hendrickson WA, Sodroski JG (1998) The antigenic structure of the HIV gp120 envelope glycoprotein. Nature 393:705-711

Yang G, Holl TM, Liu Y, Li Y, Lu X, Nicely NI, Kepler TB, Alam SM, Liao HX, Cain DW et al (2013) Identification of autoantigens recognized by the $2 \mathrm{~F} 5$ and $4 \mathrm{E} 10$ broadly neutralizing HIV-1 antibodies. J Exp Med 210:241-256

Ye L, Wen Z, Dong K, Wang X, Bu Z, Zhang H, Compans RW, Yang C (2011) Induction of HIV neutralizing antibodies against the MPER of the HIV envelope protein by HA/gp41 chimeric proteinbased DNA and VLP vaccines. PLoS ONE 6:e14813

Yi G, Lapelosa M, Bradley R, Mariano TM, Dietz DE, Hughes S, Wrin T, Petropoulos C, Gallicchio E, Levy RM et al (2013) Chimeric rhinoviruses displaying MPER epitopes elicit anti-HIV neutralizing responses. PLoS ONE 8:e72205

Yi G, Tu X, Bharaj P, Guo H, Zhang J, Shankar P, Manjunath N (2015) Human rhinovirus presenting 4E10 epitope of HIV-1 
MPER elicits neutralizing antibodies in human ICAM-1 transgenic mice. Mol Ther 23:1663-1670

Yu Y, Tong P, Li Y, Lu Z, Chen Y (2014) 10E8-like neutralizing antibodies against HIV-1 induced using a precisely designed conformational peptide as a vaccine prime. Sci China Life Sci 57:117-127

Yu Y, Fu L, Shi Y, Guan S, Yang L, Gong X, Yin H, He X, Liu D, Kuai $Z$ et al (2015) Elicitation of HIV-1 neutralizing antibodies by presentation of $4 \mathrm{E} 10$ and 10E8 epitopes on Norovirus $P$ particles. Immunol Lett 168:271-278

Zanetti G, Briggs JA, Grunewald K, Sattentau QJ, Fuller SD (2006) Cryo-electron tomographic structure of an immunodeficiency virus envelope complex in situ. PLoS Pathog 2:e83

Zang Y, Du D, Li N, Su W, Liu X, Zhang Y, Nie J, Wang Y, Kong W, Jiang $C$ (2015) Eliciting neutralizing antibodies against the membrane proximal external region of HIV-1 Env by chimeric live attenuated influenza A virus vaccines. Vaccine 33:38593864

Zhai Y, Zhong Z, Zariffard M, Spear GT, Qiao L (2013) Bovine papillomavirus-like particles presenting conserved epitopes from membrane-proximal external region of HIV-1 gp41 induced mucosal and systemic antibodies. Vaccine 31:5422-5429

Zhang R, Verkoczy L, Wiehe K, Munir Alam S, Nicely NI, Santra S, Bradley T, Pemble CW, Zhang J, Gao F et al (2016) Initiation of immune tolerance-controlled HIV gp41 neutralizing B cell lineages. Sci Transl Med. https://doi.org/10.1126/scitransImed. aaf0618

Zhou MK, Kostoula I, Brill B, Panou E, Sakarellos-Daitsiotis M, Dietrich U (2012) Prime boost vaccination approaches with different conjugates of a new HIV-1 gp41 epitope encompassing the membrane proximal external region induce neutralizing antibodies in mice. Vaccine 30:1911-1916

Zhu P, Liu J, Bess J Jr, Chertova E, Lifson JD, Grise H, Ofek GA, Taylor KA, Roux KH (2006) Distribution and three-dimensional structure of AIDS virus envelope spikes. Nature 441:847-852

Zolla-Pazner S, Powell R, Yahyaei S, Williams C, Jiang X, Li W et al (2016) Rationally-designed vaccines targeting the $V 2$ region of HIV-1 gp120 induce a focused, cross clade-reactive, biologically functional antibody response. J Virol 90:10993-11006

Zwick MB, Labrijn AF, Wang M, Spenlehauer C, Saphire EO, Binley JM, Moore JP, Stiegler G, Katinger H, Burton DR et al (2001) Broadly neutralizing antibodies targeted to the membrane-proximal external region of human immunodeficiency virus type 1 glycoprotein gp41. J Virol 75:10892-10905

Zwick MB, Komori HK, Stanfield RL, Church S, Wang M, Parren PW, Kunert R, Katinger H, Wilson IA, Burton DR (2004) The long third complementarity-determining region of the heavy chain is important in the activity of the broadly neutralizing anti-human immunodeficiency virus type 1 antibody 2F5. J Virol 78:31553161

Zwick MB, Jensen R, Church S, Wang M, Stiegler G, Kunert R, Katinger H, Burton DR (2005) Anti-human immunodeficiency virus type 1 (HIV-1) antibodies $2 \mathrm{~F} 5$ and $4 \mathrm{E} 10$ require surprisingly few crucial residues in the membrane-proximal external region of glycoprotein gp41 to neutralize HIV-1. J Virol 79:1252-1261 